\title{
ENERGY FORECASTS
}

WESTERN AUSTRALIA

1992 - 2010

\section{by}

Lee R. Charleson

and

E. Juerg Weber

Department of Economics

The University of Western Australia

DISCUSSION PAPER 92.01

MARCH 1992 


\section{ENERGY FORECASTS}

\section{WESTERN AUSTRALIA}

1992 - 2010

by

Lee R. Charleson

and

E. Juerg Weber

Department of Economics

The University of Western Australia

DISCUSSION PAPER 92.01

MARCH 1992 

Table of Contents

Introduction $\ldots \ldots \ldots \ldots \ldots \ldots \ldots \ldots \ldots \ldots \ldots \ldots \ldots \ldots \ldots \ldots \ldots \ldots$

Unconditional Forecasts $\ldots \ldots \ldots \ldots \ldots \ldots \ldots \ldots \ldots \ldots \ldots$

Model 1: Total Energy Consumption $\ldots \ldots \ldots \ldots \ldots \ldots \ldots \ldots$

Model 2: Primary Fuel Components $\ldots \ldots \ldots \ldots \ldots \ldots \ldots \ldots$

Model 3: Automotive Gasoline and Distillate $\ldots \ldots \ldots \ldots \ldots \ldots$

Model 4: Electricity $\ldots \ldots \ldots \ldots \ldots \ldots \ldots \ldots \ldots \ldots \ldots \ldots$

Real Output and Petroleum Price $\ldots \ldots \ldots \ldots \ldots \ldots \ldots \ldots \ldots \ldots$

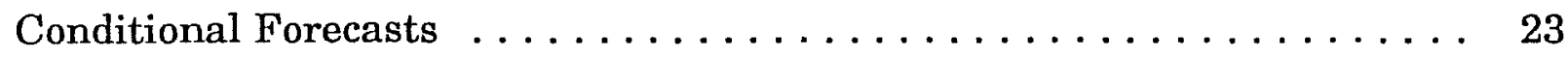

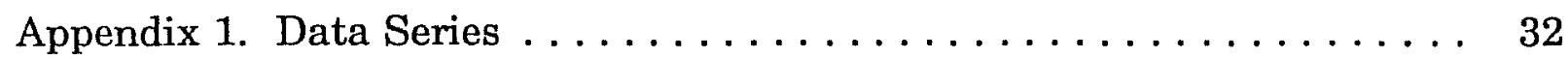

Appendix 2. Modelling with Vector Autoregressions $\ldots \ldots \ldots \ldots \ldots$

Appendix 3. Model 1: Total Energy ................ 45

Appendix 4. Model 2: Primary Fuel Components ............ 53

Appendix 5. Model 3: Petroleum Products . . . . . . . . . . . . 69

Appendix 6. Model 4: Electricity $\ldots \ldots \ldots \ldots \ldots \ldots \ldots \ldots \ldots \ldots$. 80 


\section{Introduction}

In the three decades from 1961 to 1991 , total energy consumption in Western Australia rose from 99.6 $\mathrm{PJ}^{1}$ to $467.8 \mathrm{PJ}$ - an overall increase of 370 percent at a rate of growth of 5.3 percent per year. The general upward trend in energy consumption was accompanied by large short-run fluctuations. After expanding strongly from the mid-1960s to the late 1970s, energy consumption leveled off in the wake of the second oil crisis in 1979 , and then fell by about 10 percent during the economic downturn in the early 1980s. In the second half of the 1980s, energy consumption rebounded vigorously. A notable feature of energy consumption in Western Australia is that it was unaffected by the first oil crisis in 1973/74. Figure 1 shows total energy consumption in Western Australia since 1961.

The discovery of natural gas in the remote northwestern part of the State in the 1970s has transformed Western Australia's energy sector. Natural gas now accounts for close to 40 percent of State energy consumption and its share is predicted to approach 50 percent by the end of the century. Both the rise in the price of oil and the discovery of natural gas induced large-scale substitution among fuels in the 1980s. Figure 2 shows the consumption of natural gas, petroleum products and black coal during the past three decades.

This report provides estimates of energy consumption in Western Australia to the year 2010. Four multivariate time series models are developed that capture

\footnotetext{
${ }^{1}$ One petajoule (PJ) equals $10^{15}$ joules.
} 
Total Energy Consumption

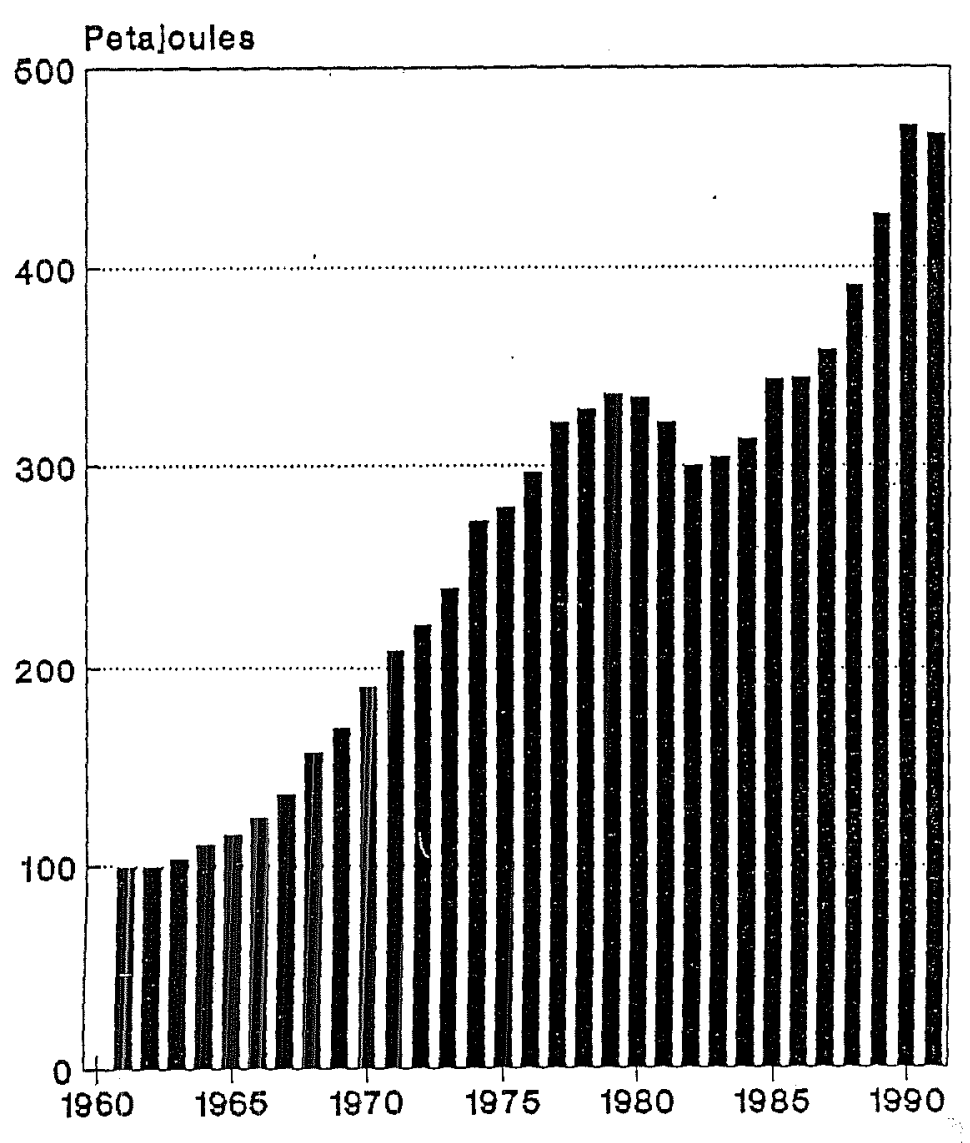

Figure 1.
Consumption of Primary

Fuel Components

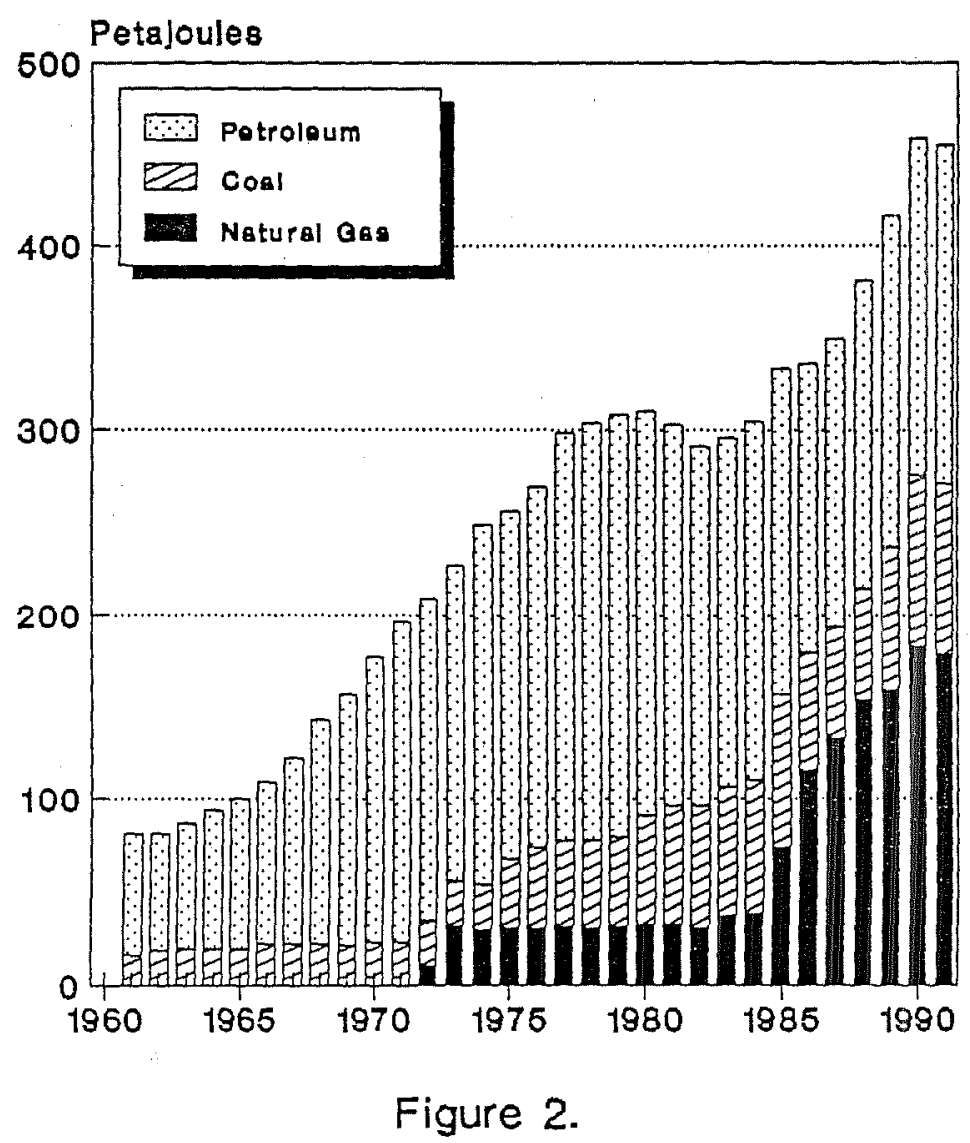


the interactions between energy consumption, energy prices and economic activity. In the second section forecasts of energy consumption and its main components are presented. In the next section the models are compared in terms of common economic variables. In the fourth section conditional energy forecasts are generated, in which the time paths of real GDP and the price of oil are preset. Included in the appendices are data series, a discussion of the use of vector autoregressions in energy forecasting, and estimated regression equations, variance decompositions and impulse responses for all models. 


\section{Unconditional Forecasts}

Four models are presented that deal with energy consumption and its principal components. The first model is concerned with total energy consumption. In the second model energy consumption is split into consumption of natural gas, black coal and petroleum products, and in the third model the consumption of petroleum products is further disaggregated into automotive gasoline and automotive distillate. The fourth model focuses on the consumption of electricity.

Multivariate time series models exploit dynamic patterns in groups of economic variables. The models in this report generate energy forecasts to the year 2010, using data on energy consumption, energy prices and aggregate output from 1961 to 1991 . All data apply to the financial year ending in June. Forecasting is based upon a "business-as-usual" scenario. In particular, it is assumed that neither fundamental changes in federal and state energy policy nor major technological breakthroughs will occur during the forecast period. However, the models do incorporate secular technological improvements by considering the long-run relationship between aggregate output and energy consumption. Note that forecasts predict energy demand without constraints on fuel availability. 


\section{Model 1: Total Energy Consumption}

Total energy consumption is defined as the total quantity of primary and derived fuels consumed less the quantity of derived fuels produced. Petroleum products that are used in a non-fuel capacity are included in total energy consumption.

The first model captures the relationships between total energy consumption (TOTE), the real price of oil (PRIC) and Australian real gross domestic product (RGDP). The estimated model is shown in Appendix 3.

Total energy demand is predicted to rise from 467.8 PJ in 1991 to $619.2 \mathrm{PJ}$ in 2010. This amounts to an overall increase of about one-third or a rate of growth of 1.5 percent per year. Following the historical pattern, the predicted rate of growth in total energy consumption displays large fluctuations in the short-run. It will fall from 3.9 percent in 1992 to a low of 0.15 percent by 1998 , and then rebound and peak at 2 percent in 2006/07. For a complete range of annual estimates refer to Figure 3, and Tables 1 and 2.

These estimates show that total energy consumption will grow by less than the historical average of $\mathbf{5 . 3}$ percent for the past three decades. It should be noted, however, that there was a break in the trend in the early $1980 \mathrm{~s}$. 


\section{Total Energy Consumption}

Forecast 1992 to 2010

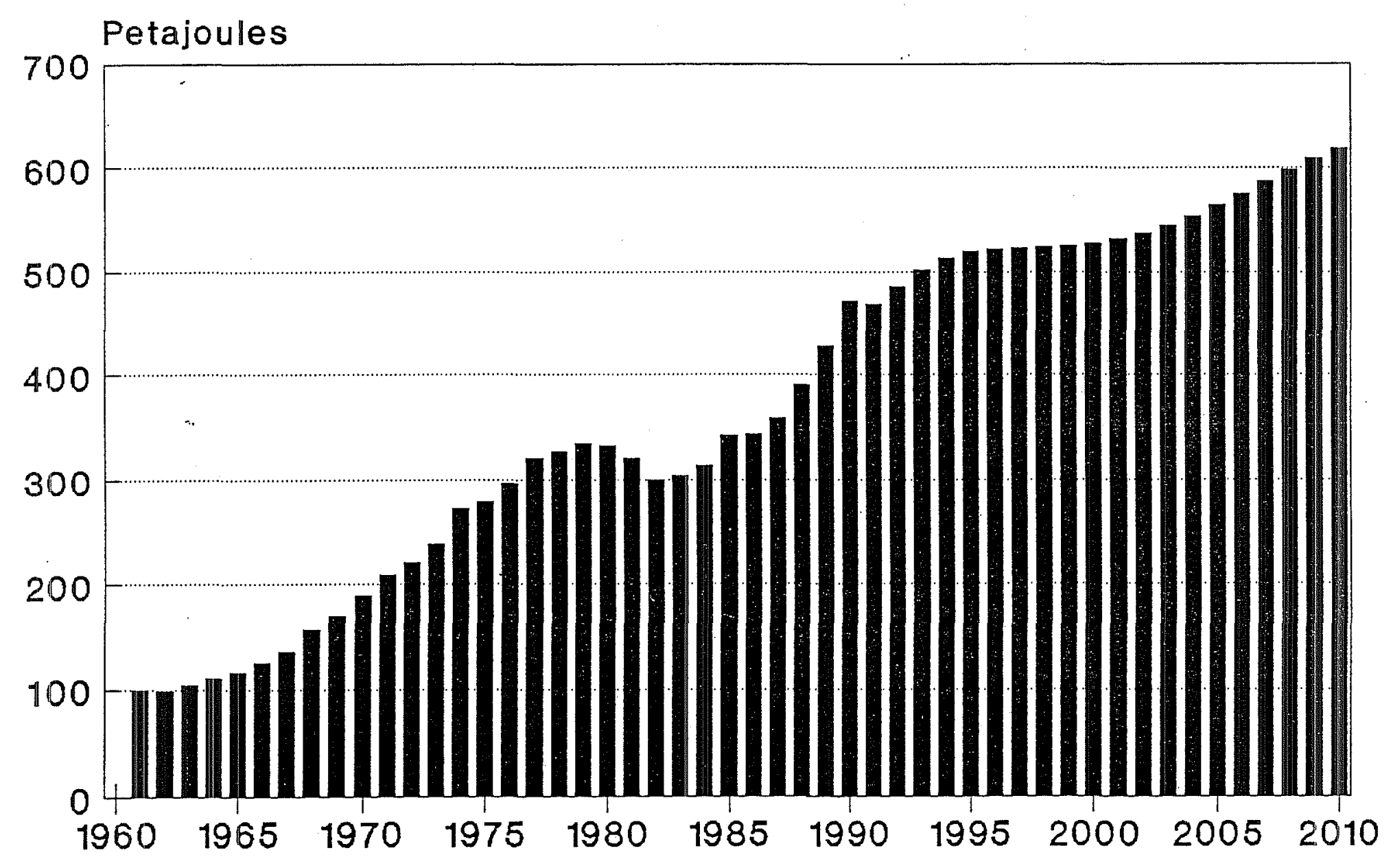

Figure 3. 
Table 1 .

Forecasts 1992 to 2010

\begin{tabular}{llll}
\hline \hline & TOTE & RRIC & RGDP \\
\hline 1991 & 467.8 & 4.045 & 256.8 \\
1992 & 486.1 & 4.402 & 260.1 \\
1993 & 502.2 & 4.978 & 263.1 \\
1994 & 513.2 & 5.612 & 266.2 \\
1995 & 519.2 & 6.164 & 269.2 \\
1996 & 521.8 & 6.625 & 271.9 \\
1997 & 522.9 & 6.933 & 274.9 \\
1998 & 523.7 & 7.137 & 278.1 \\
1999 & 524.9 & 7.242 & 281.7 \\
2000 & 527.2 & 7.249 & 285.5 \\
2001 & 531.0 & 7.179 & 289.5 \\
2002 & 536.7 & 7.052 & 293.7 \\
2003 & 544.3 & 6.898 & 297.9 \\
2004 & 553.4 & 6.740 & 302.0 \\
2005 & 563.9 & 6.599 & 306.0 \\
2006 & 575.2 & 6.488 & 309.9 \\
2007 & 586.8 & 6.419 & 313.4 \\
2008 & 598.3 & 6.394 & 316.7 \\
2009 & 609.2 & 6.413 & 319.7 \\
2010 & 619.1 & 6.469 & 322.4 \\
\hline
\end{tabular}

Table 2 .

Growth rates (in percent)

\begin{tabular}{lrrr}
\hline \hline & TOTE & PRIC & RGDP \\
\hline 1992 & 3.91 & 8.81 & 1.27 \\
1993 & 3.31 & 13.07 & 1.18 \\
1994 & 2.18 & 2.74 & 1.16 \\
1995 & 1.17 & 9.83 & 1.12 \\
1996 & .50 & 7.47 & 1.01 \\
1997 & .20 & 4.65 & 1.07 \\
1998 & .15 & 2.94 & 1.17 \\
1999 & .23 & 1.46 & 1.28 \\
2000 & .43 & .10 & 1.36 \\
2001 & .73 & -.97 & 1.41 \\
2002 & 1.07 & -1.75 & 1.43 \\
2003 & 1.40 & -2.18 & 1.42 \\
2004 & 1.68 & -2.28 & 1.39 \\
2005 & 1.88 & -2.10 & 1.33 \\
2006 & 2.00 & -1.67 & 1.24 \\
2007 & 2.02 & -1.07 & 1.14 \\
2008 & 1.95 & -.38 & 1.04 \\
2009 & 1.81 & .29 & .94 \\
2010 & 1.63 & .88 & .84 \\
\hline
\end{tabular}




\section{Model 2: Primary Fuel Components}

In recent years, three primary fuel types have dominated total energy consumption. In 1991, natural gas, black coal and petroleum products accounted for 38, 20 and 39 percent, respectively, of all energy consumed in Western Australia. The remaining 3 percent of energy was gained from fuels such as wood, thermal electricity and solar energy.

The second model considers the relationships between natural gas (NGAS), black coal (COAL) and petroleum products (PETR), the real price of oil and real GDP. The estimated model is shown in Appendix 4.

The energy equivalent of the combined consumption of natural gas, black coal and petroleum products is predicted to reach 623.0 PJ by the year 2010. This projection is very close to the total energy consumption forecast in model 1.

Consumption of natural gas, black coal and petroleum products will rise to 294, 151 and 177 PJ, respectively, by the year 2010. The overall changes for each of those fuels are 65.5, 62 and -4 percent. In 2010, the three fuel components will account for 47.3, 24.3 and 28.4 percent of total energy consumption. This demonstrates the increasing importance of natural gas as a fuel in Western Australia and the declining importance of petroleum. Despite the presence of gas as a strong competitor, coal will remain a major fuel type and its predicted share 
in total energy consumption will rise slightly. The annual forecasts for model 2 are presented in Figure 4, and Tables 3 and 4.

The consumption of natural gas is predicted to decline over the first three years of the forecast period. However, a turnaround occurs in 1995. The rate of growth will peak at 7.3 percent in 1999 , after which growth continues at a decreasing rate.

The growth rate of coal consumption is predicted to peak at 5.1 percent in 1994. The long-term growth rate will then settle at a fairly constant rate of 2 percent per year.

The consumption of petroleum products is predicted to increase somewhat over the first three years of the forecast period and then decline. The years after 2000 show a flattening of petroleum consumption. 


\section{Consumption of Primary Fuel Components Forecast 1992 to 2010}

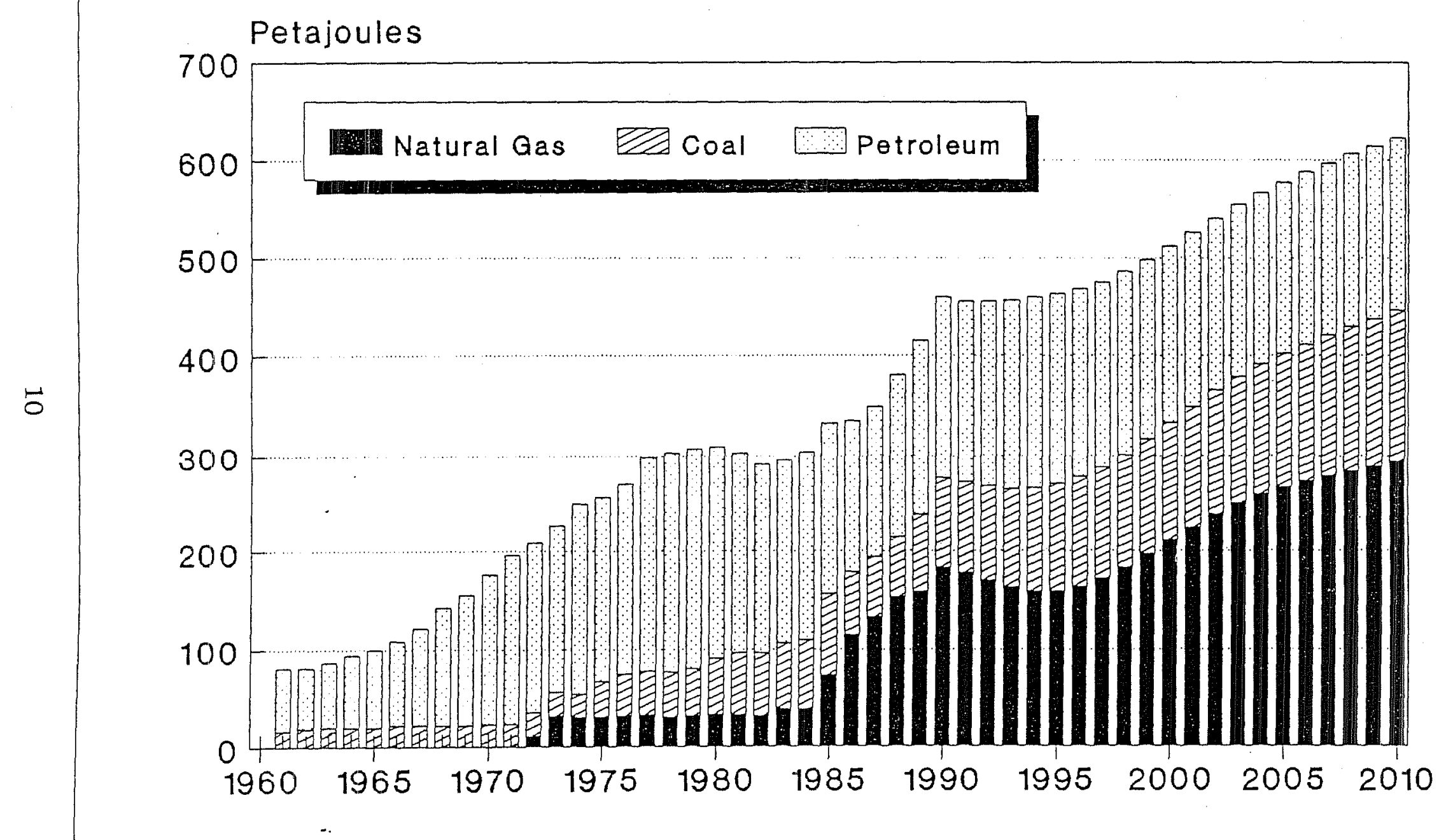

Figure 4. 
Table 3 .

Forecasts 1992 to 2010

\begin{tabular}{llrl}
\hline \hline & NGAS & COAL & PETR \\
\hline 1991 & 178.0 & 93.4 & 184.0 \\
1992 & 170.2 & 96.6 & 188.5 \\
1993 & 162.6 & 101.3 & 192.3 \\
1994 & 158.4 & 106.5 & 194.0 \\
1995 & 158.7 & 110.6 & 193.2 \\
1996 & 163.4 & 113.4 & 190.6 \\
1997 & 171.9 & 115.6 & 187.4 \\
1998 & 183.3 & 117.8 & 184.1 \\
1999 & 196.6 & 120.1 & 181.1 \\
2000 & 210.7 & 122.4 & 178.7 \\
2001 & 224.6 & 124.8 & 176.9 \\
2002 & 237.3 & 127.4 & 175.9 \\
2003 & 248.5 & 130.2 & 175.4 \\
2004 & 257.9 & 133.1 & 175.4 \\
2005 & 265.8 & 136.2 & 175.8 \\
2006 & 272.5 & 139.3 & 176.2 \\
2007 & 278.3 & 142.4 & 176.6 \\
2008 & 283.8 & 145.4 & 176.9 \\
2009 & 289.1 & 148.4 & 177.1 \\
2010 & 294.6 & 151.2 & 177.0 \\
\hline
\end{tabular}

PRIC RGDP

\begin{tabular}{lll}
\hline 1991 & 4.045 & 256.8 \\
1992 & 4.348 & 260.1 \\
1993 & 4.738 & 263.9 \\
1994 & 5.199 & 268.4 \\
1995 & 5.595 & 273.0 \\
1996 & 5.898 & 277.5 \\
1997 & 6.049 & 282.2 \\
1998 & 6.074 & 287.4 \\
1999 & 6.004 & 292.8 \\
2000 & 5.869 & 298.3 \\
2001 & 5.701 & 303.8 \\
2002 & 5.529 & 309.2 \\
2003 & 5.376 & 314.4 \\
2004 & 5.259 & 319.4 \\
2005 & 5.185 & 324.1 \\
2006 & 5.154 & 328.6 \\
2007 & 5.157 & 332.9 \\
2008 & 5.186 & $337 . .1$ \\
2009 & 5.231 & 341.2 \\
2010 & 5.280 & 345.1 \\
\hline
\end{tabular}


Table 4.

Growth rates (in percent)

\begin{tabular}{lrrr}
\hline & NGAS & PETR & COAL \\
\hline 1992 & -4.33 & 2.45 & 1.73 \\
1993 & -4.45 & 2.05 & 2.40 \\
1994 & -2.63 & .84 & 2.52 \\
1995 & .19 & -.38 & 1.91 \\
1996 & 2.98 & -1.33 & 1.25 \\
1997 & 5.19 & -1.71 & .97 \\
1998 & 6.63 & -1.75 & .94 \\
1999 & 7.26 & -1.60 & .95 \\
2000 & 7.17 & -1.33 & .96 \\
2001 & 6.56 & -.98 & .97 \\
2002 & 5.66 & -.60 & 1.02 \\
2003 & 4.69 & -.25 & 1.07 \\
2004 & 3.80 & .01 & 1.12 \\
2005 & 3.06 & .17 & 1.14 \\
2006 & 2.51 & .24 & 1.13 \\
2007 & 2.14 & .24 & 1.10 \\
2008 & 1.94 & .17 & 1.06 \\
2009 & 1.88 & .08 & 1.00 \\
2010 & 1.89 & -.02 & .94 \\
\hline
\end{tabular}

\begin{tabular}{lrl} 
& PRIC & RGDP \\
\hline 1992 & 7.47 & 1.29 \\
1993 & 8.98 & 1.48 \\
1994 & 9.71 & 1.69 \\
1995 & 7.62 & 1.70 \\
1996 & 5.41 & 1.64 \\
1997 & 2.56 & 1.71 \\
1998 & .40 & 1.81 \\
1999 & -1.14 & 1.88 \\
2000 & -2.24 & 1.88 \\
2001 & -2.86 & 1.84 \\
2002 & -3.02 & 1.76 \\
2003 & -2.76 & 1.67 \\
2004 & -2.16 & 1.58 \\
2005 & -1.40 & 1.48 \\
2006 & -.61 & 1.39 \\
2007 & .06 & 1.31 \\
2008 & .56 & 1.25 \\
2009 & .85 & 1.20 \\
2010 & .95 & 1.16 \\
\hline
\end{tabular}




\section{Model 3: Automotive Gasoline and Distillate}

This model considers the transport industry's use of petroleum products. In 1991, automotive gasoline and automotive distillate accounted for 56.3 and 77.3 PJ of total State petroleum consumption of 184.0 PJ. Combined, the two products made-up-72.6\% of petroleum consumed in 1991.

This model focuses on the relationships between consumption of leaded and unleaded gasoline (AGAS), automotive distillate (ADIS), the real price of oil and real GDP. The estimated model is presented in Appendix 5.

The forecasts indicate a continued increase in the consumption of automotive gasoline and distillates. This implies that the proportion of automotive fuels in petroleum-derived products will expand because the overall consumption of petroleum products is predicted to remain almost unchanged for the forecast period (model 2). By 2010, the two types of automotive fuel will account for 93.3 percent of the total petroleum consumption. Annual estimates for automotive gasoline and distillate are shown in Figure 5, and Tables 5 and 6.

The growth rate of automotive gasoline consumption is predicted to peak at 1.9 percent in 1994 , after which it progressively falls to only 0.5 percent by the year 2010. The growth rate of automotive distillate consumption peaks at 1.8 percent in 1998, and subsequently falls as well. The ratio of automotive gasoline to distillate will fluctuate slightly around 0.7 during the forecast period. 


\section{Consumption of Petroleum Components}

Forecast 1992 to 2010

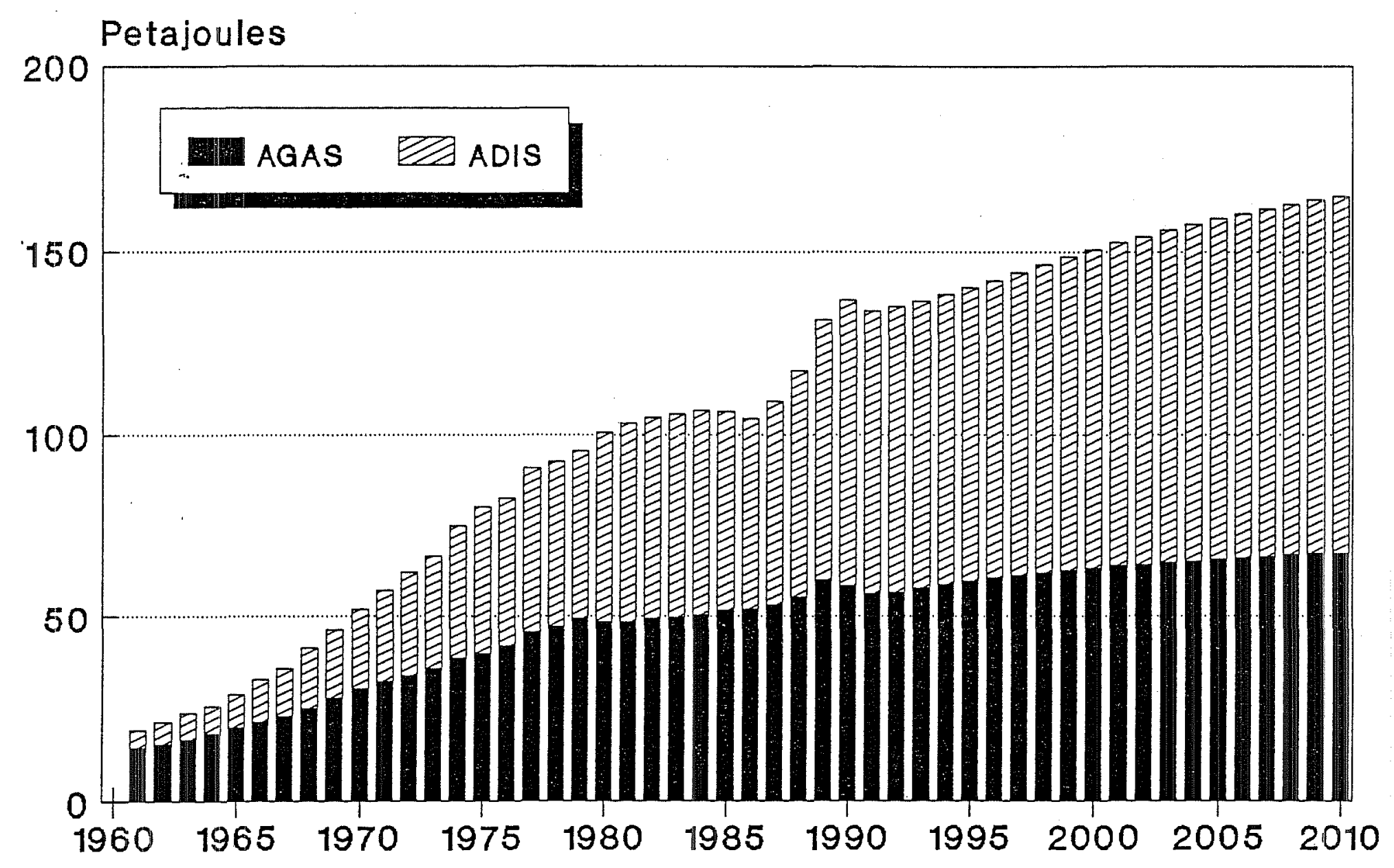

Figure 5. 
Table 5 .

Forecasts 1992 to 2010

\begin{tabular}{lllll}
\hline \hline & AGAS & ADIS & PRIC & RGDP \\
\hline 1991 & 56.30 & 77.30 & 4.045 & 256.8 \\
1992 & 56.74 & 78.27 & 4.441 & 259.0 \\
1993 & 57.78 & 78.91 & 4.758 & 261.9 \\
1994 & 58.88 & 79.45 & 4.946 & 265.7 \\
1995 & 59.80 & 80.41 & 5.025 & 269.9 \\
1996 & 60.58 & 81.66 & 5.056 & 273.8 \\
1997 & 61.31 & 83.06 & 5.041 & 277.7 \\
1998 & 61.99 & 84.55 & 5.025 & 281.5 \\
1999 & 62.61 & 86.04 & 5.023 & 285.1 \\
2000 & 63.19 & 87.45 & 5.035 & 288.5 \\
2001 & 63.72 & 88.79 & 5.059 & 291.8 \\
2002 & 64.22 & 90.02 & 5.089 & 294.9 \\
2003 & 64.70 & 91.18 & 5.122 & 297.9 \\
2004 & 65.15 & 92.26 & 5.154 & 300.7 \\
2005 & 65.58 & 93.28 & 5.183 & 303.5 \\
2006 & 65.99 & 94.25 & 5.207 & 306.1 \\
2007 & 66.38 & 95.18 & 5.226 & 308.7 \\
2008 & 66.75 & 96.06 & 5.240 & 311.2 \\
2009 & 67.11 & 96.92 & 5.250 & 313.6 \\
2010 & 67.44 & 97.74 & 5.256 & 315.9 \\
\hline
\end{tabular}

Table 6.

Growth rates (in percent)

\begin{tabular}{lrrrr}
\hline & AGAS & ADIS & PRIC & RGDP \\
\hline 1992 & .79 & 1.26 & 9.77 & .87 \\
1993 & 1.82 & .81 & 7.14 & 1.09 \\
1994 & 1.90 & .68 & 3.94 & 1.45 \\
1995 & 1.56 & 1.21 & 1.60 & 1.58 \\
1996 & 1.30 & 1.55 & .62 & 1.47 \\
1997 & 1.20 & 1.70 & -.30 & 1.41 \\
1998 & 1.10 & 1.79 & -.31 & 1.35 \\
1999 & 1.00 & 1.75 & -.04 & 1.28 \\
2000 & .91 & 1.64 & .24 & 1.20 \\
2001 & .84 & 1.52 & .47 & 1.13 \\
2002 & .78 & 1.39 & .59 & 1.06 \\
2003 & .74 & 1.28 & .64 & 1.00 \\
2004 & .70 & 1.18 & .62 & .95 \\
2005 & .66 & 1.10 & .56 & .91 \\
2006 & .62 & 1.03 & .36 & .87 \\
2007 & .59 & .98 & .26 & .84 \\
2008 & .55 & .93 & .18 & .77 \\
2009 & .52 & .89 & .11 & .74 \\
2010 & .49 & .85 & & .96 \\
\hline
\end{tabular}




\section{Model 4: Electricity}

Electricity is a derived energy source that is generated from oil, gas, coal and, to a limited extent, wind. In Western Australia coal is currently the predominant fuel converted to electricity. Electricity data refer to all sectors which use electricity including industrial, commercial and residential. The industrial sector is the largest consumer of electricity. The electricity data do not include electricity generated and co-generated in the industrial sector.

The fourth model examines the relationships between electricity consumption (ELEC) and real GDP. The estimated model is presented in Appendix 6.

In 1991, the energy equivalent of consumed electricity was $47.0 \mathrm{PJ}$. By 2010 , the predicted electricity consumption will reach 74.3 PJ - an increase of 58 percent. The annual growth peaks at 3.6 percent in 1993; thereafter, it progressively slows to 1.5 percent by the end of the forecast period. The mean growth is 2.5 percent. Annual estimates are shown in Figure 6, and Tables 7 and 8 . 


\section{Electricity Consumption}

Forecast 1992 to 2010

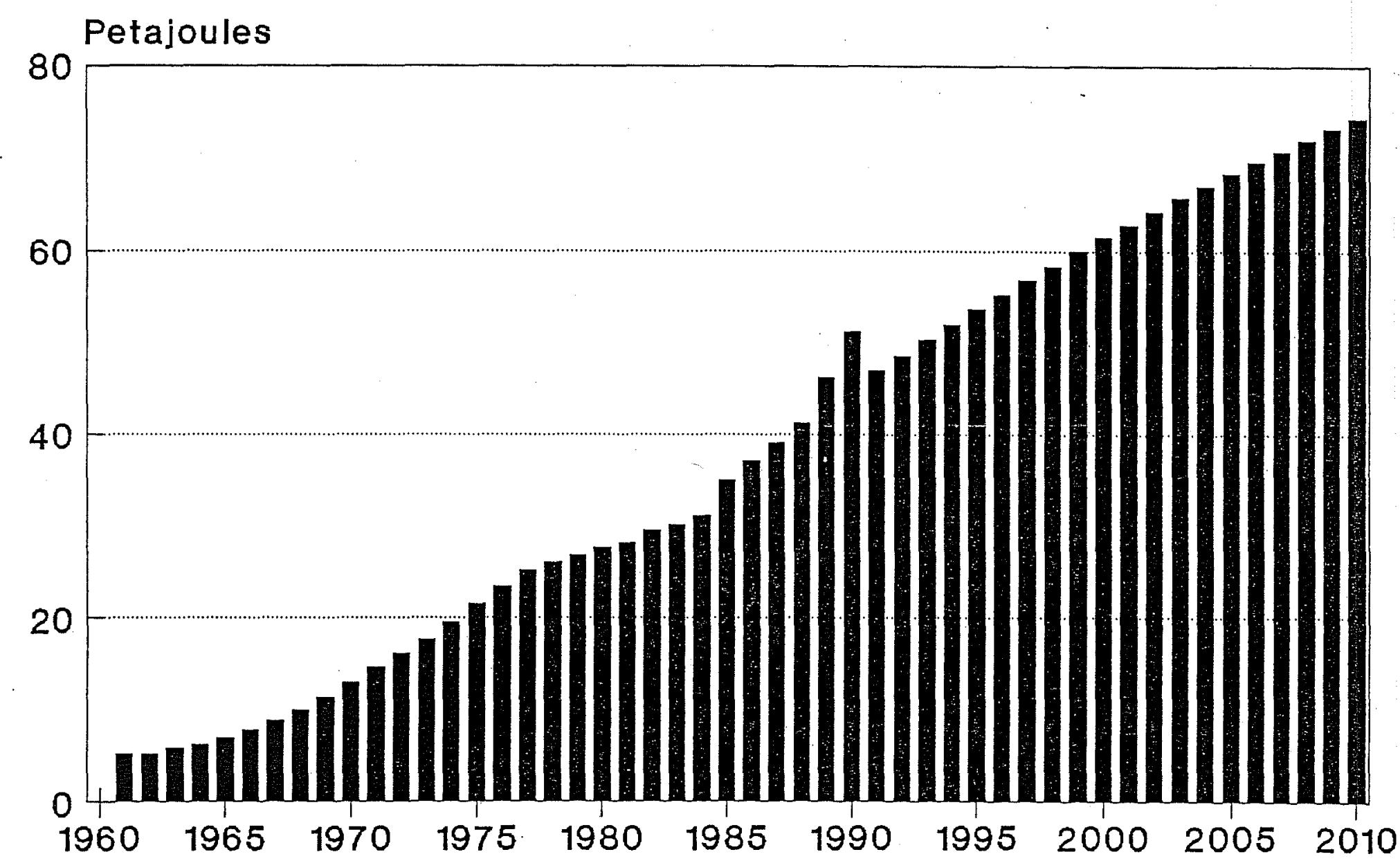

Figure 6. 
Table 7 .

Forecasts 1992 to 2010

\begin{tabular}{lll}
\hline \hline & ELEC & RGDP \\
\hline 1991 & 47.00 & 256.8 \\
1992 & 48.58 & 261.4 \\
1993 & 50.36 & 266.1 \\
1994 & 52.04 & 270.6 \\
1995 & 53.65 & 275.1 \\
1996 & 55.25 & 279.4 \\
1997 & 56.86 & 283.6 \\
1998 & 58.43 & 287.6 \\
1999 & 59.97 & 291.6 \\
2000 & 61.46 & 295.4 \\
2001 & 62.91 & 299.1 \\
2002 & 64.32 & 302.7 \\
2003 & 65.70 & 306.2 \\
2004 & 67.04 & 309.6 \\
2005 & 68.34 & 312.8 \\
2006 & 69.60 & 316.0 \\
2007 & 70.83 & 319.0 \\
2008 & 72.02 & 322.0 \\
2009 & 73.18 & 324.8 \\
2010 & 74.30 & 327.5 \\
\hline
\end{tabular}

Table 8 .

Growth rate (in percent)

\begin{tabular}{lll}
\hline \hline & ELEC & RGDP \\
\hline 1992 & 3.36 & 1.82 \\
1993 & 3.68 & 1.77 \\
1994 & 3.33 & 1.71 \\
1995 & 3.08 & 1.63 \\
1996 & 2.98 & 1.55 \\
1997 & 2.91 & 1.49 \\
1998 & 2.76 & 1.43 \\
1999 & 2.62 & 1.37 \\
2000 & 2.48 & 1.31 \\
2001 & 2.36 & 1.25 \\
2002 & 2.24 & 1.20 \\
2003 & 2.13 & 1.14 \\
2004 & 2.03 & 1.10 \\
2005 & 1.93 & 1.05 \\
2006 & 1.84 & 1.00 \\
2007 & 1.76 & .96 \\
2008 & 1.68 & .92 \\
2009 & 1.60 & .88 \\
2010 & 1.53 & .84 \\
\hline
\end{tabular}




\section{Real Output and Petroleum Price}

Since all variables are jointly determined in vector autoregressions, the models in this report can also be used to generate forecasts of the real price of oil and real GDP. The forecast of those variables are shown in Tables 1,3, 5 and 7, and Figures 7 and 8.

It should be noted, however, that the models are primarily designed to forecast energy consumption. The real price of oil and real GDP are included because variance decompositions and impulse responses show that these variables are suitable to predict energy consumption. On the other hand, the models are much less capable of predicting the real price of oil and real GDP. Energy consumption in Western Australia does not affect the real price of oil - which is determined in world markets - and energy consumption has also only a minor impact on Australian real GDP. For this reason, it is not. surprising that the energy forecasts of the four models are consistent in the sense that the subaggregates in models 2 and 3 add up to the aggregate figures in models 1 and 2 , whereas there is some variation in the forecast on the real price of oil and real GDP across models.

The forecasts of the real price of oil and real GDP do provide useful information. The first model, for example, predicts that the real price of oil will increase until the year 2000 and then fall, and that real output will expand slowly in the 1990s and at a faster rate at the turn of the century. High energy prices 


\section{Australian Real GDP \\ Forecast 1992 to 2010}

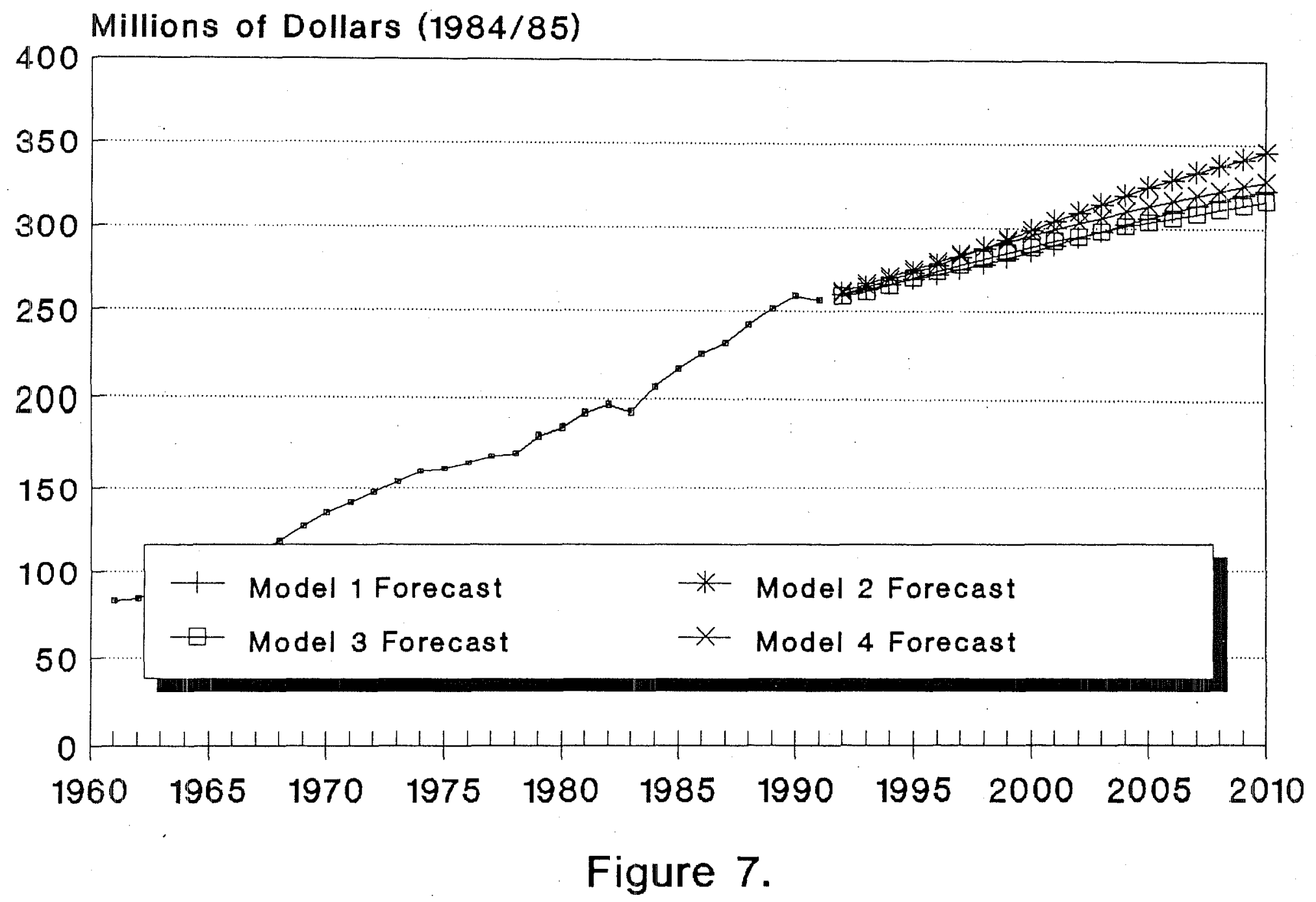




\section{Real Petroleum Price}

Forecast 1992 to 2010

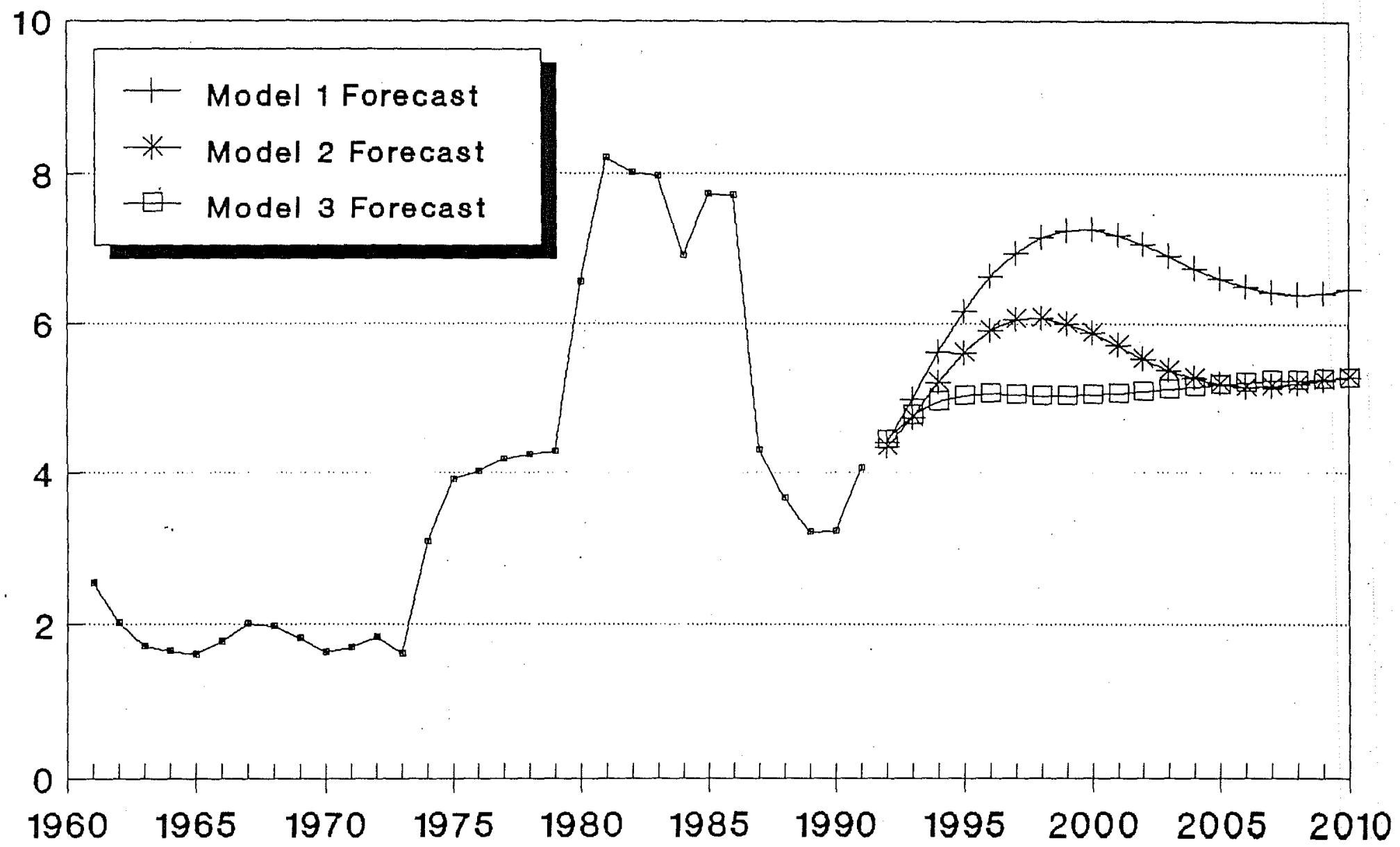

Figure 8. 
and low real GDP growth thus explain why the rate of growth of total energy consumption will remain depressed in the 1990s. After 1998, the two effects are reversed and energy consumption grows at an increasing rate.

Similarly, price and income effects explain why, in the second model, consumption of natural gas and black coal are predicted to increase rapidly, whereas consumption of petroleum products will remain almost constant. Both the high price of oil and the continuous expansion in real output feed the consumption of natural gas and black coal, whereas price and income effects offset each other in the case of petroleum products. For the third and fourth models, it is necessary to review the variance decompositions and impulse responses in Appendix 2 in order to determine the relative importance of price and income effects on energy consumption. 


\section{Conditional Forecasts}

VAR models are systems of dynamic equations that determine the time paths of a group of variables. In conditional forecasts the time paths of some variables are set in advance for the forecast period. In this section it is assumed that the real price of oil is constant and real GDP will grow at 3 percent per year until the year 2010 .

The conditional energy forecasts are shown in Figures 9 to 12 and Tables 8 to 11 . The conditional forecasts exceed the unconditional ones because the internally generated projection of real GDP growth is less than three percent per year. Most of the difference between unconditional and conditional forecasts arises after the year 2000. A comparison of conditional and unconditional forecasts shows:

Model 1: The conditional forecast of total energy demand exceeds the unconditional forecast by 11.9 percent in the year 2000 and by 57.7 percent in 2010. The revised forecast for the year 2005 is now very close to that of the Australian Bureau of Agricultural and Resource Economics (Table D6).

Model 2: Higher real GDP growth primarily leads to a rise in the demand for natural gas, whereas the demand for petrol and coal does not change much. This is in keeping with the variance decompositions, which show 
that natural gas depends on real GDP, whereas petroleum and coal are largely independent of GDP (pp. 59-60).

Model 3: The conditional forecast for the demand for automotive distillate exceeds the unconditional forecast by 10.5 percent in the year 2000 and by 30.3 percent in the year 2010. The difference among forecasts is much smaller for automotive gasoline. The variance decompositions again show that the demand for automotive distillate is more responsive to real GDP than the demand for gasoline (p. 71).

Model 4. The conditional forecast for electricity demand exceeds the unconditional forecast by $\mathbf{1 7 . 9}$ percent in the year 2000 and 58.5 percent in the year 2010.

An important finding of this report is that State energy consumption strongly depends on real GDP. Therefore, energy forecasts would benefit from improved GDP forecasts. Time and funding prevented further research into the determinants of real GDP. 


\section{Total Energy Consumption}

Conditional Forecast 1992 to 2010

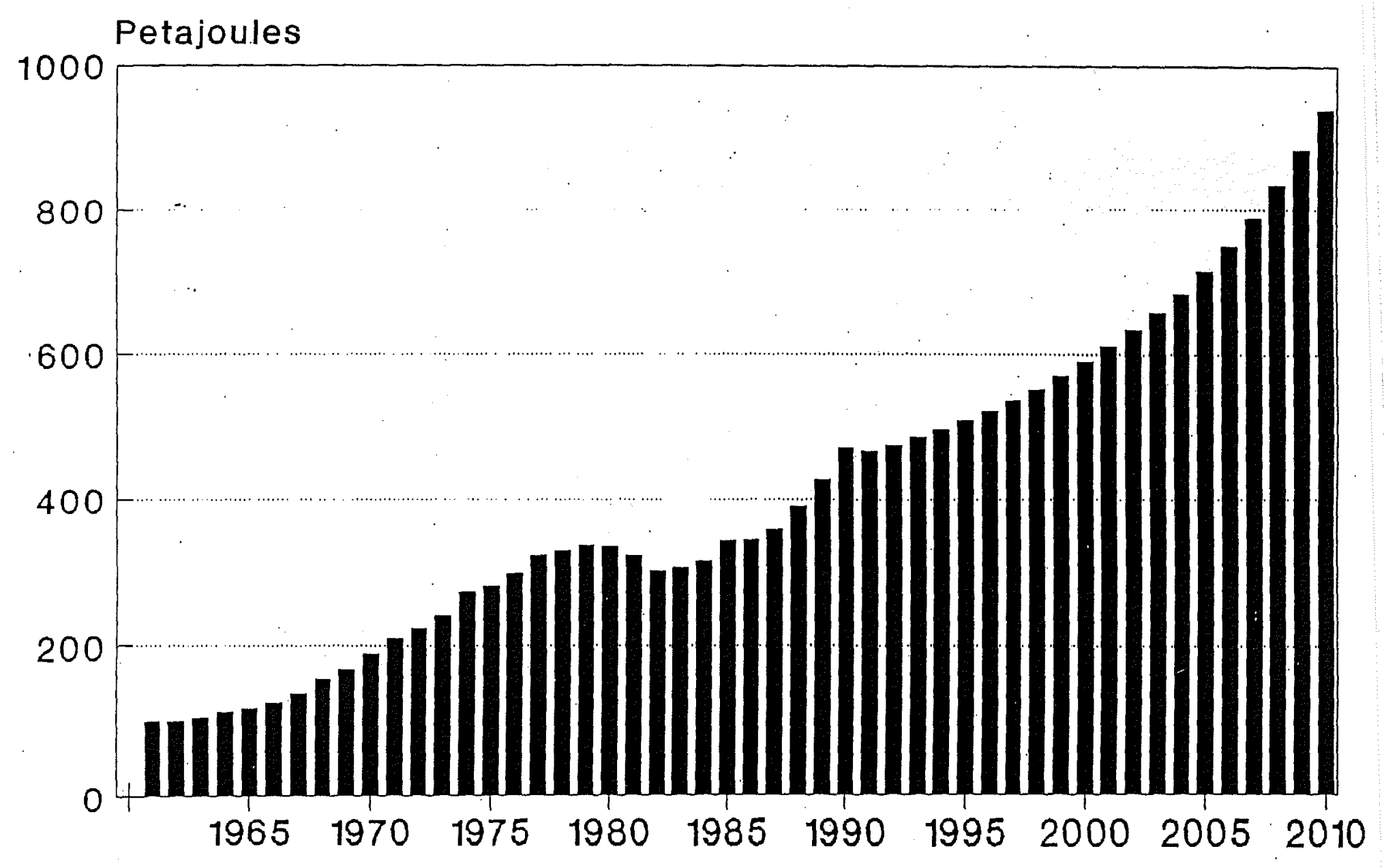

Figure 9. 


\section{Consumption of Primary Fuel Component}

Conditional Forecast 1992 to 2010

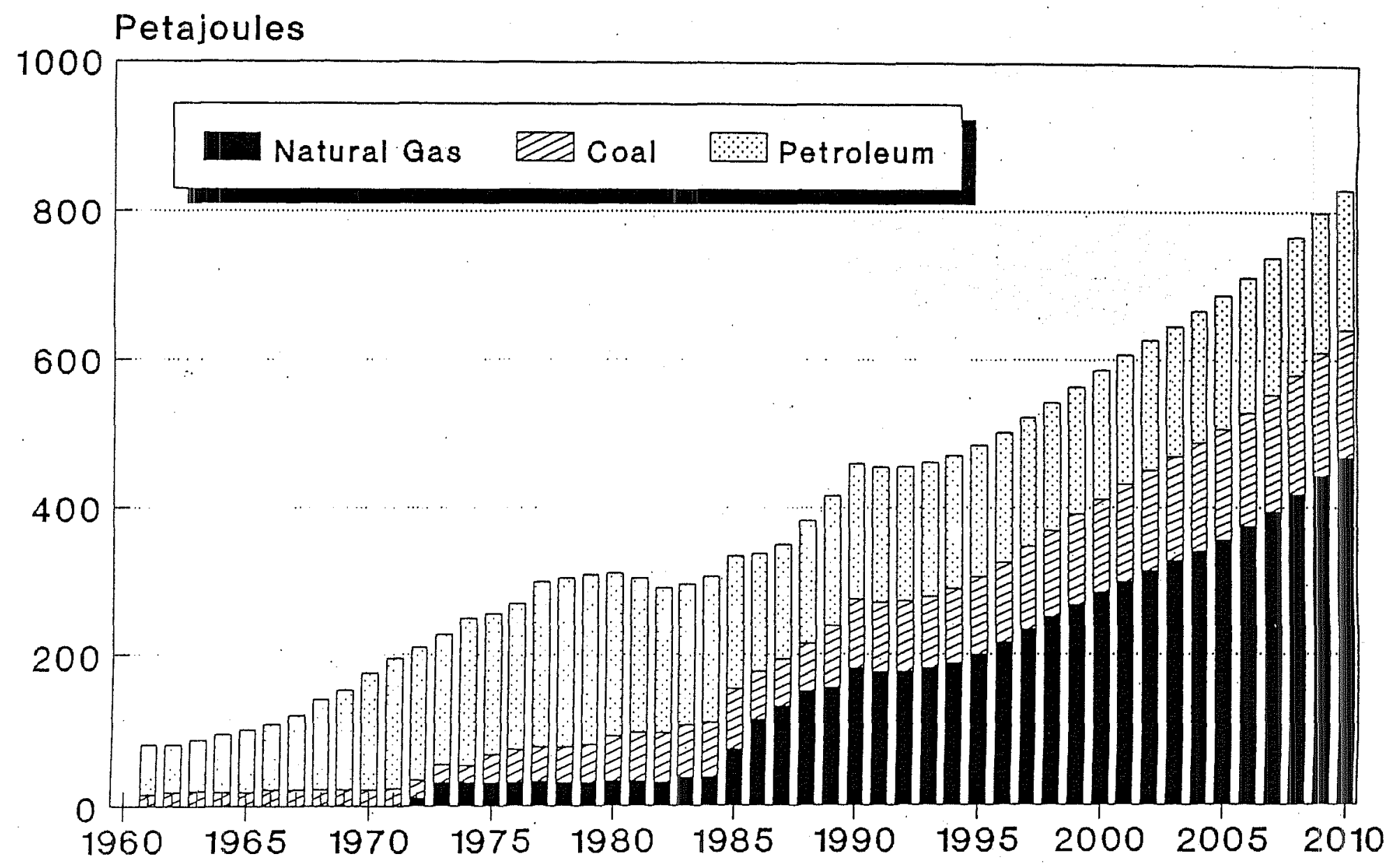

Figure 10. 


\section{Consumption of Petroleum Components Conditional Forecast 1992 to 2010}

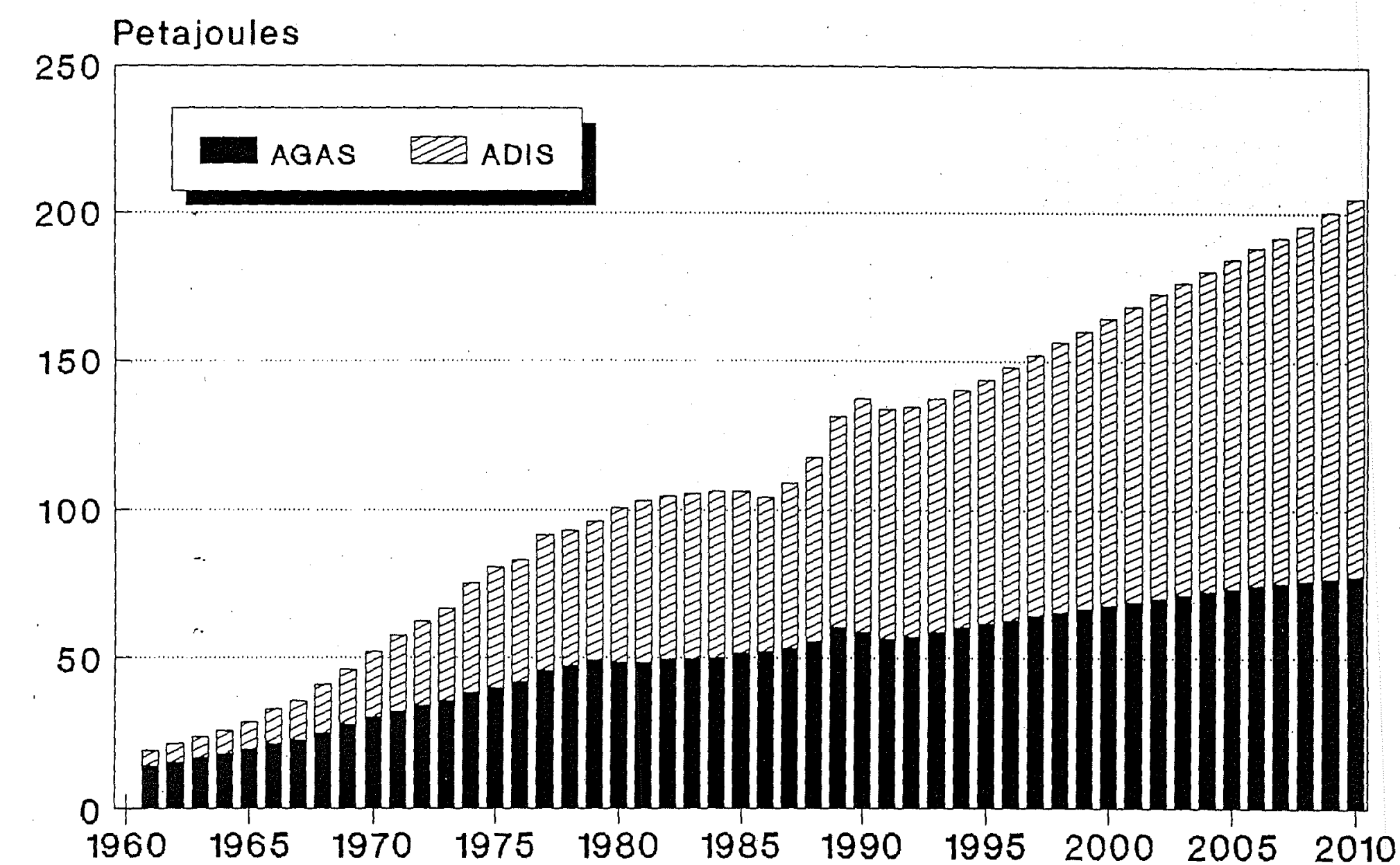

Figure 11. 


\section{Electricity Consumption Conditional Forecast 1992 to 2010}

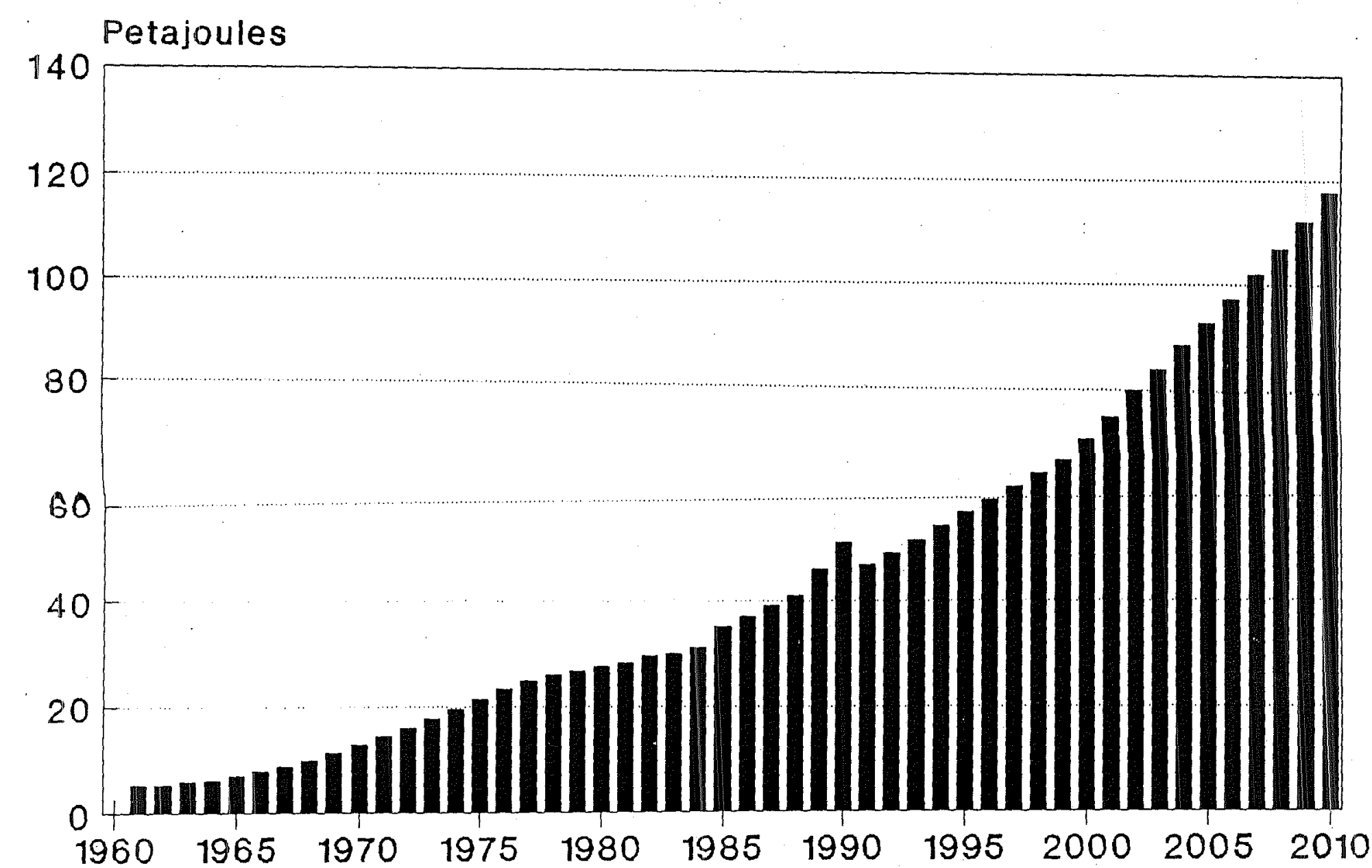

Figure 12. 
Table 8 .

Total Energy Consumption

\begin{tabular}{llll}
\hline \hline & TOTE & PRIC & RGDP \\
\hline 1992 & 475.5 & 4.045 & 264.5 \\
1993 & 486.1 & 4.045 & 272.4 \\
1994 & 497.3 & 4.045 & 280.6 \\
1995 & 509.4 & 4.045 & 289.0 \\
1996 & 522.7 & 4.045 & 297.7 \\
1997 & 537.5 & 4.045 & 306.6 \\
1998 & 553.7 & 4.045 & 315.8 \\
1999 & 571.2 & 4.045 & 325.3 \\
2000 & 590.1 & 4.045 & 335.1 \\
2001 & 610.4 & 4.045 & 345.1 \\
2002 & 632.3 & 4.045 & 355.5 \\
2003 & 656.3 & 4.045 & 366.1 \\
2004 & 683.0 & 4.045 & 377.1 \\
2005 & 713.2 & 4.045 & 388.4 \\
2006 & 747.7 & 4.045 & 400.1 \\
2007 & 787.7 & 4.045 & 412.1 \\
2008 & 833.6 & 4.045 & 424.4 \\
2009 & 884.9 & 4.045 & 437.2 \\
2010 & 939.0 & 4.045 & 450.3 \\
\hline
\end{tabular}


Table 9.

Primary Fuel Components

\begin{tabular}{llll}
\hline & NGAS & COAI & PETR \\
\hline 1992 & 179.2 & 93.7 & 182.5 \\
1993 & 182.7 & 96.1 & 181.4 \\
1994 & 189.6 & 100.1 & 180.2 \\
1995 & 200.8 & 104.6 & 178.6 \\
1996 & 215.7 & 108.6 & 177.1 \\
1997 & 232.7 & 112.8 & 175.7 \\
1998 & 250.5 & 117.4 & 174.8 \\
1999 & 267.8 & 122.4 & 174.4 \\
2000 & 284.2 & 127.4 & 174.4 \\
2001 & 299.2 & 132.4 & 175.0 \\
2002 & 313.0 & 137.3 & 176.0 \\
2003 & 326.3 & 142.2 & 177.3 \\
2004 & 340.0 & 147.1 & 178.9 \\
2005 & 355.4 & 151.6 & 180.6 \\
2006 & 373.3 & 155.6 & 182.2 \\
2007 & 394.0 & 158.9 & 184.0 \\
2008 & 417.4 & 162.6 & 185.7 \\
2009 & 442.8 & 167.2 & 187.5 \\
2010 & 467.4 & 172.6 & 189.6 \\
\hline
\end{tabular}

\begin{tabular}{lll} 
& PRIC & RGDP \\
\hline 1992 & 4.045 & 264.5 \\
1993 & 4.045 & 272.4 \\
1994 & 4.045 & 280.6 \\
1995 & 4.045 & 289.0 \\
1996 & 4.045 & 297.7 \\
1997 & 4.045 & 306.6 \\
1998 & 4.045 & 315.8 \\
1999 & 4.045 & 325.3 \\
2000 & 4.045 & 335.1 \\
2001 & 4.045 & 345.1 \\
2002 & 4.045 & 355.5 \\
2003 & 4.045 & 366.1 \\
2004 & 4.045 & 377.1 \\
2005 & 4.045 & 388.4 \\
2006 & 4.045 & 400.1 \\
2007 & 4.045 & 412.1 \\
2008 & 4.045 & 424.4 \\
2009 & 4.045 & 437.2 \\
2010 & 4.045 & 450.3 \\
\hline
\end{tabular}


Table 10.

Petroleum Products

\begin{tabular}{lllll}
\hline \hline & AGAS & ADIS & PRIC & RGDP \\
\hline 1992 & 57.17 & 77.3 & 4.045 & 264.5 \\
1993 & 58.75 & 78.2 & 4.045 & 272.4 \\
1994 & 60.30 & 79.7 & 4.045 & 280.6 \\
1995 & 61.61 & 82.2 & 4.045 & 289.0 \\
1996 & 62.82 & 85.0 & 4.045 & 297.7 \\
1997 & 64.03 & 88.0 & 4.045 & 306.6 \\
1998 & 65.25 & 90.9 & 4.045 & 315.8 \\
1999 & 66.46 & 93.8 & 4.045 & 325.3 \\
2000 & 67.67 & 96.6 & 4.045 & 335.1 \\
2001 & 68.87 & 99.5 & 4.045 & 345.1 \\
2002 & 70.04 & 102.5 & 4.045 & 355.5 \\
2003 & 71.17 & 105.5 & 4.045 & 366.1 \\
2004 & 72.24 & 108.3 & 4.045 & 377.1 \\
2005 & 73.23 & 111.1 & 4.045 & 388.4 \\
2006 & 74.15 & 113.8 & 4.045 & 400.1 \\
2007 & 75.04 & 116.6 & 4.045 & 412.1 \\
2008 & 75.89 & 119.8 & 4.045 & 424.4 \\
2009 & 76.73 & 123.4 & 4.045 & 437.2 \\
2010 & 77.58 & 127.3 & 4.045 & 450.3 \\
\hline
\end{tabular}

Table 11.

Electricity.

\begin{tabular}{lrl}
\hline \hline & ELEC & RGDP \\
\hline 1992 & 49.1 & 264.5 \\
1993 & 51.6 & 272.4 \\
1994 & 54.2 & 280.6 \\
1995 & 56.8 & 289.0 \\
1996 & 59.6 & 297.7 \\
1997 & 62.6 & 306.6 \\
1998 & 65.7 & 315.8 \\
1999 & 69.0 & 325.3 \\
2000 & 72.5 & 335.1 \\
2001 & 76.1 & 345.1 \\
2002 & 79.9 & 355.5 \\
2003 & 83.9 & 366.1 \\
2004 & 88.1 & 377.1 \\
2005 & 92.4 & 388.4 \\
2006 & 97.0 & 400.1 \\
2007 & 101.8 & 412.1 \\
2008 & 106.9 & 424.4 \\
2009 & 112.2 & 437.2 \\
2010 & 117.7 & 450.3 \\
\hline
\end{tabular}


Appendix 1.

Data Series 
Consumption of automotive distillate in Western Australia.

Units: PJ

Source: Energy Policy and Planning Bureau

\section{AGAS}

Consumption of automotive gasoline, leaded and unleaded, in Western Australia.

Units: PJ

Source: Energy Policy and Planning Bureau

\section{COAL}

Consumption of black coal in Western Australia.

Units: PJ

Source: Energy Policy and Planning Bureau

\section{ELEC}

Consumption of electricity in Western Australia.

Electricity series were spliced by multiplying data prior to 1974 by a factor of 1.88 .

Units: PJ

Source: Energy Policy and Planning Bureau

\section{NGAS}

Consumption of natural gas in Western Australia.

Units: PJ

Source: Energy Policy and Planning Bureau

\section{PETR}

Consumption of petroleum products in Western Australia.

Units: PJ

Source: Energy Policy and Planning Bureau

\section{PRIC}

Real price of crude oil.

Units: Nominal price divided by GDP deflator

Source: International Financial Statistics, $\mathrm{TMF}$

\section{RGDP}

Real Australian gross domestic product.

Units: Millions of dollars (1984/85)

Source: ABS

\section{TOTE}

Total energy consumption in Western Australia.

Units: P.J

Source: Energy Policy and Planning Bureau 


\begin{tabular}{|c|c|c|c|}
\hline & TOTE & PRIC & RGDP \\
\hline 1961 & 99.6000 & 2.51524 & 83023.0 \\
\hline 1962 & 99.1000 & 2.01232 & 84363.0 \\
\hline 1963 & 103.900 & 1.70189 & 89711.0 \\
\hline 1964 & 110.800 & 1.64096 & 95992.0 \\
\hline 1965 & 115.900 & 1.59867 & 102743. \\
\hline 1966 & 124.600 & 1.75983 & 105870. \\
\hline 1967 & 136.200 & 2.00323 & 112138 . \\
\hline 1968 & 157.100 & 1.95904 & 117475 . \\
\hline 1969 & 169.400 & 1.80921 & 126742 . \\
\hline 1970 & 189.800 & 1.63361 & 134823 . \\
\hline 1971 & 209.100 & 1.69265 & 141222 . \\
\hline 1972 & 221.700 & 1.82987 & 147679 . \\
\hline 1973 & 239.100 & 1.61587 & 153936 . \\
\hline 1974 & 272.600 & 3.07152 & 160649. \\
\hline 1975 & 279.500 & 3.89558 & 162981 . \\
\hline 1976 & 296.500 & 4.01311 & 167045 . \\
\hline 1977 & 321.800 & 4.17399 & 172330 . \\
\hline 1978 & 328.200 & 4.24252 & 173882 . \\
\hline 1979 & 335.800 & 4.28133 & 182758 . \\
\hline 1980 & 334.100 & 6.55048 & 186611. \\
\hline 1981 & 322.000 & 8.20238 & 193043. \\
\hline 1982 & 300.100 & 8.01207 & 197200 . \\
\hline 1983 & 304.600 & 7.95572 & 193835. \\
\hline 1984 & 313.900 & 6.91154 & 205546 . \\
\hline 1985 & 343.100 & 7.72141 & 216266 . \\
\hline 1986 & 344.200 & 7.70937 & 225087 \\
\hline 1987 & 358.400 & 4.30345 & 231264 . \\
\hline 1988 & 391.000 & 3.64221 & 241676. \\
\hline 1989 & 427.600 & .3 .19295 & 251203 . \\
\hline 1990 & 471.600 & 3.20287 & 259436. \\
\hline 1991 & 467.800 & 4.04577 & 256820 \\
\hline
\end{tabular}




\begin{tabular}{llll}
\hline \hline 1961 & 0.000000 & 16.7000 & 64.1000 \\
1962 & 0.000000 & 19.5000 & 61.5000 \\
1963 & 0.000000 & 20.4000 & 66.1000 \\
1964 & 0.000000 & 19.7000 & 74.4000 \\
1965 & 0.000000 & 20.0000 & 79.8000 \\
1966 & 0.000000 & 22.3000 & 86.8000 \\
1967 & 0.000000 & 22.3000 & 99.0000 \\
1968 & 0.000000 & 22.5000 & 120.200 \\
1969 & 0.100000 & 21.7000 & 133.700 \\
1970 & 0.300000 & 22.9000 & 153.300 \\
1971 & 0.600000 & 23.3000 & 172.300 \\
1972 & 11.4000 & 23.7000 & 174.100 \\
1973 & 32.5000 & 23.2000 & 171.300 \\
1974 & 31.2000 & 23.0000 & 194.600 \\
1975 & 31.5000 & 36.1000 & 187.900 \\
1976 & 31.9000 & 42.5000 & 194.900 \\
1977 & 32.8000 & 45.1000 & 220.400 \\
1978 & 31.3000 & 46.1000 & 226.000 \\
1979 & 32.2000 & 47.6000 & 228.100 \\
1980 & 33.1000 & 57.6000 & 218.800 \\
1981 & 33.6000 & 62.5000 & 206.600 \\
1982 & 31.9000 & 64.4000 & 194.900 \\
1983 & 38.3000 & 67.9000 & 189.100 \\
1984 & 38.6000 & 71.1000 & 194.900 \\
1985 & 73.9000 & 82.4000 & 177.100 \\
1986 & 115.300 & 63.7000 & 156.500 \\
1987 & 132.900 & 60.6000 & 155.600 \\
1988 & 153.000 & 61.1000 & 166.800 \\
1989 & 158.500 & 78.8000 & 178.900 \\
1990 & 183.300 & 92.2000 & 184.100 \\
1991 & 178.000 & 93.4000 & 184.000 \\
\hline & & &
\end{tabular}




\begin{tabular}{llll} 
& AGAS & ADIS & ELEC \\
\hline \hline 1961 & 14.3982 & 4.82500 & 5.29723 \\
1962 & 15.4242 & 6.06020 & 5.30900 \\
1963 & 16.7922 & 6.98660 & 5.87845 \\
1964 & 18.2628 & 7.48840 & 6.30996 \\
1965 & 19.7676 & 8.87800 & 7.07408 \\
1966 & 21.5118 & 11.4256 & 7.85363 \\
1967 & 22.9140 & 12.8152 & 8.92248 \\
1968 & 25.0344 & 16.1734 & 10.0214 \\
1969 & 27.8388 & 18.6438 & 11.4445 \\
1970 & 30.4038 & 21.6160 & 12.9936 \\
1971 & 32.2848 & 25.1672 & 14.5660 \\
1972 & 34.0290 & 28.4482 & 16.0958 \\
1973 & 35.5680 & 30.9572 & 17.6794 \\
1974 & 38.4066 & 36.6314 & 19.5000 \\
1975 & 39.8772 & 40.5686 & 21.5000 \\
1976 & 42.1344 & 40.8388 & 23.4000 \\
1977 & 45.6570 & 45.6638 & 25.1000 \\
1978 & 47.3670 & 45.7024 & 26.0000 \\
1979 & 49.3848 & 46.7060 & 26.8000 \\
1980 & 48.4272 & 52.2644 & 27.6000 \\
1981 & 48.4614 & 54.6962 & 28.2000 \\
1982 & 49.6242 & 54.9664 & 29.5000 \\
1983 & 49.7610 & 55.8156 & 30.1000 \\
1984 & 50.3082 & 56.2016 & 31.1000 \\
1985 & 51.6078 & 54.8120 & 35.0000 \\
1986 & 52.0866 & 52.4188 & 37.1000 \\
1987 & 53.3178 & 55.6612 & 39.2000 \\
1988 & 55.4382 & 62.1460 & 41.2000 \\
1989 & 60.1920 & 71.0240 & 46.3000 \\
1990 & 58.6188 & 78.3580 & 51.2000 \\
1991 & 56.3000 & 77.3000 & 47.0000 \\
\hline & & &
\end{tabular}


Appendix 2.

Modelling with Vector Autoregressions 


\section{Modelling with Vector Autoregressions}

In univariate time series analysis, a time series, such as total energy consumption, is viewed as a series of random variables. If those random variables are correlated, future values of the series can then be forecast. Unlike structural econometric models, time series models are purely statistical, taking advantage of inherent patterns in variables. Table 2.1 shows the serial correlation in total energy consumption, using data from 1961 to 1991 . The correlation coefficients start at 0.9 for the first lag and fall to 0.36 for the sixth lag.

Recent advances in econometrics have lead to multivariate time series models which take account of the interactions between two or more variables. ${ }^{2}$ In multivariate time series models, a group of variables is considered to be generated by a vector stochastic process. Table 2.2 shows the joint serial correlation among the variables in model 1. For example, the correlation between total energy consumption in period $t$ and real GDP in period ( $t-2)$ equals 0.77 .

A vector autoregression (VAR) model consists of a set of equations in which each variable is regressed on its own lagged $v$ alues and on the lagged values of all other variables in the model. The model can be written as:

${ }^{2}$ See the seminal paper by Sims, $C$. A. Macroeconomics and Reality, Econometrica 48, January 1980. Reprinte in C.W.J. Granger, ed., Modelling Economic Series, Clarendon Press, Oxford, 990. 
Table 2.1

Autocorrelation of total energy consumption

\begin{tabular}{cl}
\hline Lags & $\begin{array}{l}\text { Correlation } \\
\text { coefficient }\end{array}$ \\
\hline 1 & 0.9046 \\
2 & 0.7918 \\
3 & 0.6800 \\
4 & 0.5717 \\
5 & 0.4658 \\
6 & 0.3629 \\
\hline
\end{tabular}

Table 2.2

Cross correlation between

total energy consumption and real GDP

\begin{tabular}{|c|c|}
\hline Lags & $\begin{array}{l}\text { Correlation } \\
\text { coefficient }\end{array}$ \\
\hline 1 & 0.8818 \\
\hline 2 & 0.7699 \\
\hline 3 & 0.6668 \\
\hline 4 & 0.5742 \\
\hline 5 & 0.4931 \\
\hline 6 & 0.4121 \\
\hline
\end{tabular}




$$
y_{(t)}=\sum_{s=1}^{E} \beta_{(s)} \cdot y_{(t-s)}+\mu_{(t)}
$$

where $y$ is a $n$-vector of variables and $\beta(s)$ is a $n \times n$ matrix of coefficients. $L$ indicates the number of lags used and $\mu$ is a vector of error terms. Appendices 3 to 6 present the estimated energy models.

VARs may be regarded as reduced forms of (unspecified) structural econometric models. For this reason, the regression coefficients do not have any meaning. The moving average representation, however, provides variance decompositions and impulse responses that highlight the relationships among the variables in the model. Variance decompositions and impulse responses are included in Appendices 3 to 6 following the estimated models.

A variable is statistically exogenous if most of the variance of its forecast error is due to its own innovations, rather than to innovations in the other variables in the model. Consider, for example, the first model. The real price of oil is an exogenous variable because most of its forecast error is due to its own innovations. Independent shocks to the price of oil account for 96.4 percent of the four-year forecast error and for 83.8 percent of the eight-year forecast error. Similarly, real GDP is an exogenous variable. On the other hand, local energy consumption depends on the real price of oil and real GDP. Shocks to the price of oil account for 28.1 percent of the four-year forecast error and shocks to real GDP account for 9.3 percent. On a longer horizon, the contribution of real GDP 

shocks to the forecast error in total energy consumption approaches one third. The impulse responses show that the price effect on energy consumption is negative and the income effect is positive.

Impulse responses must be viewed in conjunction with variance decompositions. For example, the impulse responses of model 1 also show that an increase in total energy consumption in Western Australia has a negative effect on Australian real GDP. There is no obvious theoretical justification for this effect, and the variance decompositions confirm that it is unimportant. Shocks to energy consumption account for only 1.4 percent of the four-year forecast error in real GDP.

Variance decompositions and impulse responses require orthogonalized innovations. The forecast error of a variable cannot be split into the contributions of shocks to specific variables if those shocks are correlated. Similarly, it would not be possible to assign impulse responses to shocks in specific variables. In this study, the so-called Choleski factorization is employed to orthogonalize the contemporaneous covariance matrix of residuals. As a consequence, variance decompositions depend upon the ordering of variables because, within a single time period, variables that are listed first may influence the following variables but without feedback. In model 1 it is assumed that there is a contemporaneous influence from the real price of oil - to real GDP - to total energy consumption. This assumption is justified by the fact that the price of oil is determined in world 
markets and real GDP is an economy-wide variable, whereas total energy consumption applies to Western Australia.

Vector autoregressions generally suffer from over-parametrization because each variable is regressed on its own lags and on the lags of all other variables. As a consequence, standard errors are large and forecasts are uncertain, except in very small models. Model 1 requires the estimation of 57 coefficients. The degrees of freedom problem can be overcome by a Bayesian approach that imposes normal prior distributions on the coefficients with specified means and standard deviations that decline with growing lag length. In this report, the "Minnesota prior" is adopted, which assumes that all variables follow a random walk process. ${ }^{3}$ The prior is implemented by setting the means of the first own lags equal to one and the means of all other lags equal to zero in each equation. Theil's mixed estimation technique can then be used to estimate the models.

An important issue in time series analysis concerns stationarity. Stationarity can often be achieved by differencing a series. This poses a problem when, in multivariate models, some series are stationary and others are not. Bayesian VARs provide an alternative to differencing either all series or none. By imposing prior distributions on first own lags that centre around one, the "Minnesota prior" assumes that all series are nonstationary. If this prior is

\footnotetext{
${ }^{3}$ Bayesian VARs are discussed in Todd, R.M., Improving Economic Forecasting with Bayesian Vector Autoregressions, Federal Reserve Bank of Minneapolis Quarterly Review, Fall 1984. Reprinted in C.W.J. Granger, ed., Modelling Economic Series, Clarendon Press, Oxford, 1990.
} 
inappropriate, it can easily be overridden by the data because the prior standard deviation of first lags are large.

The prior distributions of the regression coefficients are specified as independent normal distributions with the following means and standard deviations

$$
\begin{aligned}
& \mathrm{E}(\beta(\mathrm{ijs}))=\begin{array}{l}
1 \text { if } \mathrm{i}=\mathrm{j}, \mathrm{s}=1 \\
0 \text { otherwise }
\end{array} \\
& \sigma(\beta(\mathrm{ijs}))=\{\gamma \mathrm{g}(\mathrm{s}) \mathrm{f}(\mathrm{i}, \mathrm{j})\} \sigma(\mathrm{i}) / \sigma(\mathrm{j})
\end{aligned}
$$

Here, $\beta(i, j, s)$ is the coefficient of lag $s$ of variables $j$ in equation $i$. The quantities $\gamma, g(s)$ and $f(i, j)$ determine the tightness of the prior distributions of the $\beta$ coefficients. $\gamma$ controls the prior standard deviation of the first own lag since $f(i, i)$ $=g(1)=1.0$. The decay function, $g(s)$, determines the tightness of lag $\mathrm{s}$ relative to lag 1 . The function $f(i, j)$ sets the tightness of variables $j$ in equation $i$ relative to variable i. $\sigma(i)$ is the standard error of a univariate autoregression on equation i. The ratio $\sigma(i) / \sigma(j)$ scales the different magnitudes of the variables $i$ and $j$.

All models use six lags. In model 1 , the overall tightness parameter $\gamma$ equals 0.4 . The lag decay function $g(s)$ is harmonic with a decay parameter of 1 , and the function $f(i, j)$ is symmetric with $f\left(i_{2}\right)=0.5$ for $i \neq j$. Each model's prior is fully described in Appendices 3 to 6. 
The software package Regression Analysis of Time Series (RATS) by VAR Econometrics ${ }^{4}$ was used for the econometric work.

${ }^{4}$ VAR Econometrics, Inc., 1800 Sherman Ave., Suite 612, Evanston, Mlinois, USA. 
Appendix 3.

Model 1: Total Energy 
The variables in this model include total energy consumption, the real price of oil and real GDP. Total energy consumption and real GDP were converted to logarithms. The following tables show the prior distribution imposed upon the regression coefficients, the estimated regression equations, and variance decompositions and impulse responses.

The variance decompositions indicate that total energy consumption is influenced by the real price of oil and real GDP, whereas the price of oil and real GDP are both statistically exogenous. The impulse responses show that the price effect on total energy consumption is negative for eight years and the income effect is positive. The $Q$-values of the regression equations confirm that serial correlation is not a problem. Appendix 2 contains a more detailed discussion of the output of model 1.

Several additional variables were tested in model 1. For example, the State labour force was used to proxy for State real GDP. It was hypothesised that the inclusion of a State variable would account for local effects on energy consumption in Western Australia. The variance decompositions of the expanded model showed, however, that total energy consumption is independent of the State labour force if Australian real GDP is also included in the model. In fact, the variables in the expanded model explain movements in the State labour force but there is no feedback to energy consumption. For this reason, the labour force series was dropped from the model. 
THE PRIOR IS....

TIGHTNESS PARAMETER $\quad 0.40000$

HARMONIC LAG DECAY WITH PARAMETER 1.00000

MEANS AND STANDARD DEVIATIONS AS PERCENTAGE OF OWN LAG LISTED UNDER THE DEPENDENT VARIABLE

$\begin{array}{llcc} & \text { RGDP } & \text { TOTE } & \text { PRIC } \\ \text { RGDP } & 1.00000000 & 0.50000000 & 0.50000000 \\ \text { TOTE } & 0.50000000 & 1.00000000 & 0.50000000 \\ \text { PRIC } & 0.50000000 & 0.50000000 & 1.00000000 \\ \text { MEAN } & 1.00000000 & 1.00000000 & 1.00000000\end{array}$




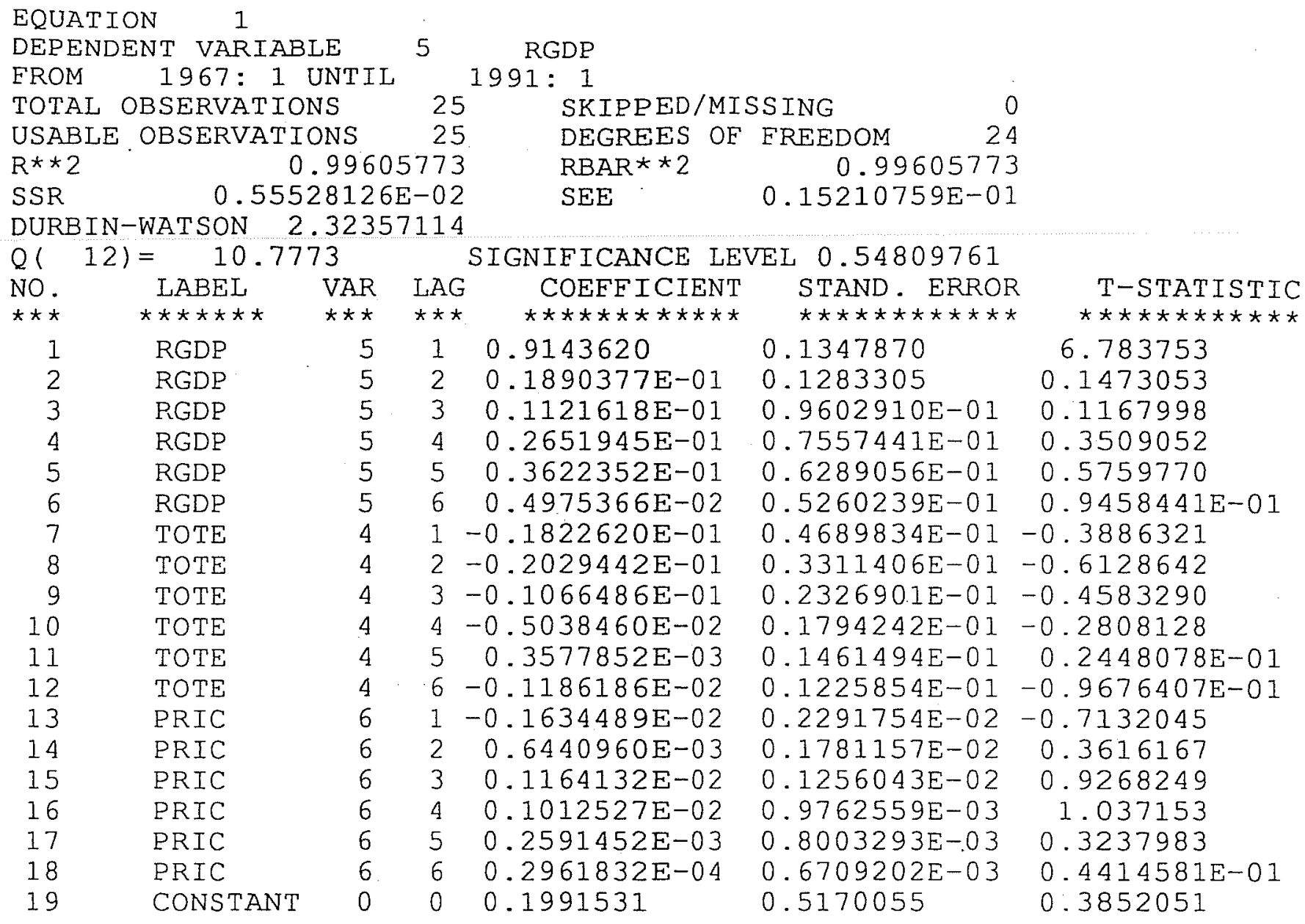




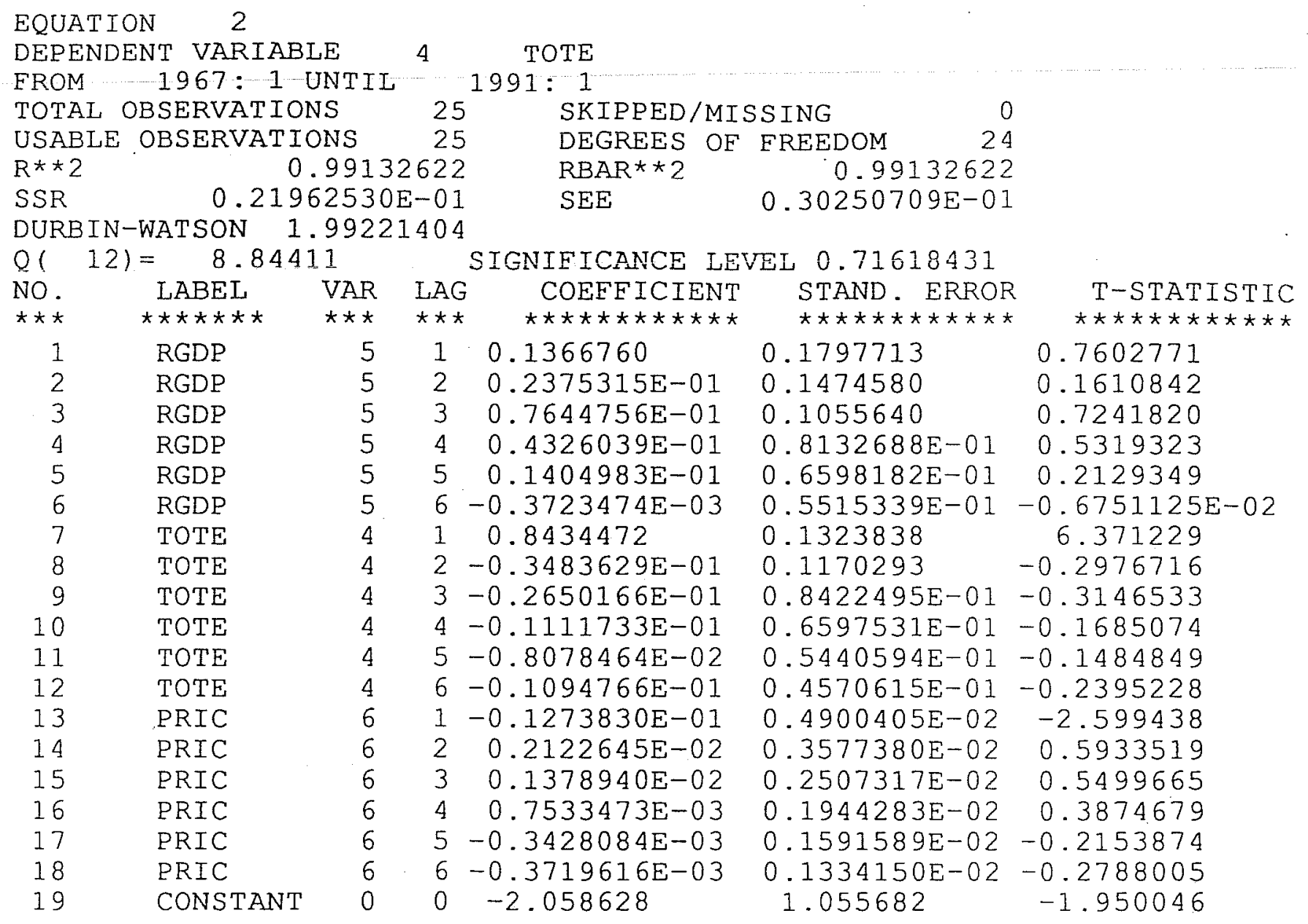




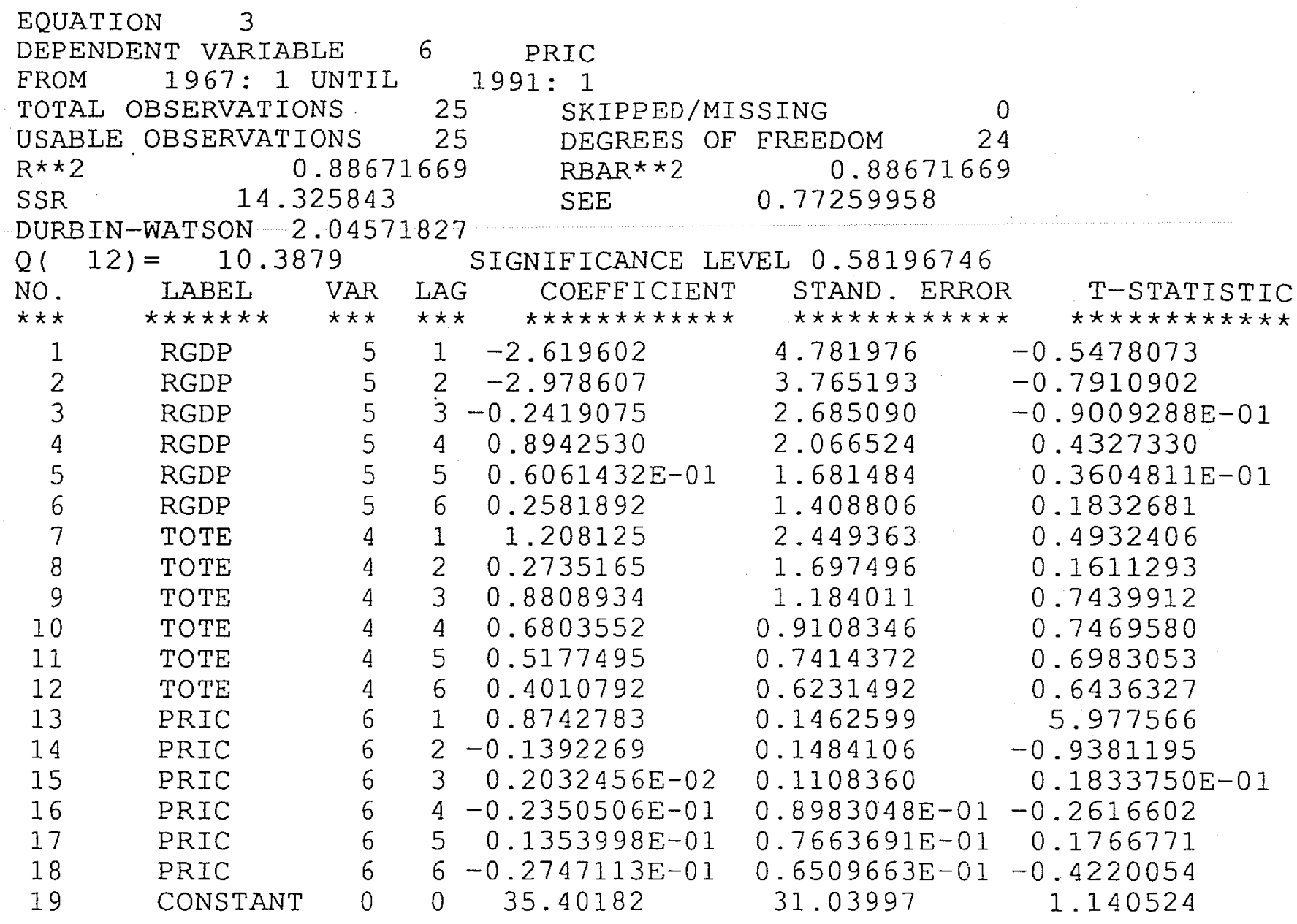


RESPONSES TO ONE-STANDARD DEVIATION SHOCK IN PRIC

\begin{tabular}{lllll} 
ENTRY & PRIC & \multicolumn{1}{c}{ RGDP } & TOTE \\
& 1 & 0.756990 & $-0.128365 \mathrm{E}-02$ & $-0.405403 \mathrm{E}-02$ \\
2 & 0.660285 & $-0.233712 \mathrm{E}-02$ & $-0.132376 \mathrm{E}-01$ \\
3 & 0.464724 & $-0.242935 \mathrm{E}-02$ & $-0.181780 \mathrm{E}-01$ \\
4 & 0.300390 & $-0.108975 \mathrm{E}-02$ & $-0.187236 \mathrm{E}-01$ \\
5 & 0.148968 & $0.111265 \mathrm{E}-02$ & $-0.165633 \mathrm{E}-01$ \\
6 & $0.305923 \mathrm{E}-01$ & $0.315774 \mathrm{E}-02$ & $-0.132163 \mathrm{E}-01$ \\
7 & $-0.879681 \mathrm{E}-01$ & $0.466875 \mathrm{E}-02$ & $-0.930045 \mathrm{E}-02$ \\
8 & -0.180304 & $0.571153 \mathrm{E}-02$ & $-0.451508 \mathrm{E}-02$ \\
9 & -0.234752 & $0.635043 \mathrm{E}-02$ & $0.555688 \mathrm{E}-03$ \\
10 & -0.253269 & $0.659275 \mathrm{E}-02$ & $0.521791 \mathrm{E}-02$ \\
11 & -0.240969 & $0.643569 \mathrm{E}-02$ & $0.897442 \mathrm{E}-02$ \\
12 & -0.205939 & $0.592941 \mathrm{E}-02$ & $0.115673 \mathrm{E}-01$
\end{tabular}

RESPONSES TO ONE-STANDARD DEVIATION SHOCK IN RGDP

\begin{tabular}{lllll} 
ENTRY & \multicolumn{1}{l}{ RRIC } & RGDP & TOTE \\
& 1 & 0.000000 & $0.148481 \mathrm{E}-01$ & $0.626320 \mathrm{E}-02$ \\
2 & $-0.313293 \mathrm{E}-01$ & $0.134623 \mathrm{E}-01$ & $0.731205 \mathrm{E}-02$ \\
3 & $-0.963360 \mathrm{E}-01$ & $0.123810 \mathrm{E}-01$ & $0.854089 \mathrm{E}-02$ \\
4 & -0.138151 & $0.115081 \mathrm{E}-01$ & $0.110908 \mathrm{E}-01$ \\
5 & -0.138000 & $0.109437 \mathrm{E}-01$ & $0.138441 \mathrm{E}-01$ \\
6 & -0.118378 & $0.106474 \mathrm{E}-01$ & $0.157470 \mathrm{E}-01$ \\
7 & $-0.855842 \mathrm{E}-01$ & $0.100654 \mathrm{E}-01$ & $0.165598 \mathrm{E}-01$ \\
8 & $-0.506226 \mathrm{E}-01$ & $0.925476 \mathrm{E}-02$ & $0.165008 \mathrm{E}-01$ \\
9 & $-0.147608 \mathrm{E}-01$ & $0.837133 \mathrm{E}-02$ & $0.158139 \mathrm{E}-01$ \\
10 & $0.204390 \mathrm{E}-01$ & $0.752324 \mathrm{E}-02$ & $0.146318 \mathrm{E}-01$ \\
11 & $0.511217 \mathrm{E}-01$ & $0.676699 \mathrm{E}-02$ & $0.130716 \mathrm{E}-01$ \\
12 & $0.744171 \mathrm{E}-01$ & $0.612235 \mathrm{E}-02$ & $0.112952 \mathrm{E}-01$
\end{tabular}

RESPONSES TO ONE-STANDARD DEVIATION SHOCK IN TOTE

\begin{tabular}{|c|c|c|c|}
\hline ENTRY & PRIC & RGDP & TOTE \\
\hline 1 & 0.000000 & 0.000000 & $0.286852 E-01$ \\
\hline 2 & $0.346553 E-01$ & $-0.522821 E-03$ & $0.241944 E-01$ \\
\hline 3 & $0.687437 \mathrm{E}-01$ & $-0.155781 \mathrm{E}-02$ & $0.188945 E-01$ \\
\hline 4 & 0.115627 & $-0.266564 \mathrm{E}-02$ & $0.133060 \mathrm{E}-01$ \\
\hline 5 & 0.165412 & $-0.360557 E-02$ & $0.788414 \mathrm{E}-02$ \\
\hline 6 & 0.206258 & $-0.418618 E-02$ & $0.274633 E-02$ \\
\hline 7 & 0.231393 & $-0.44 .7592 E-02$ & $-0.204367 E-02$ \\
\hline 8 & 0.227403 & $-0.445034 E-02$ & $-0.594862 E-02$ \\
\hline 9 & $0.199525^{\circ}$ & $-0.412054 E-02$ & $-0.871011 E-02$ \\
\hline 10 & 0.155285 & $-0.353756 E-02$ & $510 \mathrm{E}-01$ \\
\hline 11 & 0.101871 & $-0.278965 E-02$ & $-0.106425 E-0 I$ \\
\hline 12 & $0.461433 E-01$ & $-0.198183 E-02$ & $-0.100477 \mathrm{E}-01$ \\
\hline
\end{tabular}


DECOMPOSITION OE VARIANCE, SERIES

STEP
1
2
3
4
5
6
7
8
9
10
11
12

PRIC

100.0000000

99.7841647

98.6956759

96.4333296

93.3645860

89.8248033

86.3673069

83.7876743

82.3740185

81.8873956

81.8810365

81.9531525
6

PRIC

RGDP

0.0000000

0.0970659

0.8268151

2.1518306

3. 3782459

4.1884138

4. 4740098

4. 3937781

4.1661267

3.9869932

3.9754354

4.1573117

TOTE

0.0000000

0.1187695

0.4775090

1. 4148398

3. 2571681

5.9867829

9.1586833

11.8185476

13.4598548

14.1256112

14.1435280

13.8895358

\section{DECOMPOSITION OF VARIANCE, SERIES}

STEP
1
2
3
4
5
6
7
8
9
10
11
12

PRIC

0.7418525

1. 7380042

2.2799399

1.9958608

1.8259463

2.5761550

4.1795732

6.2979291

8.6138842

10.8538529

12.7950896

14.3055266
5

\section{RGDP}

RGDP

99.2581475

98.1951774

97.2469350

96.6258237

95.4765100

93.3347989

90.4758266

87.3771375

84.4215845

81.8715758

79.8759322

78.4657940
TOTE

0.0000000

0.0668183

0.4731251

1. 3783154

2. 6975437

4.0890461

5. 3446003

6. 3249334

6.9645313

7.2745713

7. 3289782

7. 2286794

\begin{tabular}{rclcl}
\multicolumn{2}{c}{ DECOMPOSITION OE VARIANCE, SERIES } & 4 & TOTE \\
STEP & STAN ERR & \multicolumn{1}{l}{ PRIC } & \multicolumn{1}{l}{ RGDP } & \multicolumn{1}{l}{ TOTE } \\
1 & $0.296395 \mathrm{E}-01$ & 1.8708140 & 4.4652973 & 93.66388 .87 \\
2 & $0.411409 \mathrm{E}-01$ & 11.3240905 & 5.4765113 & 83.1993981 \\
3 & $0.495273 \mathrm{E}-01$ & 21.2847635 & 6.7526888 & 71.9625477 \\
4 & $0.557099 \mathrm{E}-01$ & 28.1184427 & 9.3004019 & 62.5811554 \\
5 & $0.602640 \mathrm{E}-01$ & 31.5832370 & 13.2251961 & 55.1915669 \\
6 & $0.637333 \mathrm{E}-01$ & 32.5385781 & 17.9292451 & 49.5321768 \\
7 & $0.665345 \mathrm{E}-01$ & 31.8103926 & 22.6459970 & 45.5436103 \\
8 & $0.689557 \mathrm{E}-01$ & 30.0444801 & 26.8098302 & 43.1456898 \\
9 & $0.712821 \mathrm{E}-01$ & 28.1214278 & 30.0101386 & 41.8684336 \\
10 & $0.736718 \mathrm{E}-01$ & 26.8282798 & 32.0393324 & 41.1323879 \\
11 & $0.761065 \mathrm{E}-01$ & 26.5297027 & 32.9721224 & 40.4981749 \\
12 & $0.784509 \mathrm{E}-01$ & 27.1418556 & 33.1039024 & 39.7542420
\end{tabular}


Appendix 4.

Model 2: Primary Fuel Components 
This model disaggregates total energy consumption into natural gas, black coal and petroleum products. The real price of oil and real GDP are retained in the model. Real GDP was converted to logarithm. The figures on natural gas, coal and petroleum products were transformed by taking square roots instead of logarithms because the consumption of natural gas was zero before 1968 .

Tight prior distributions were imposed on coal in the equations for natural gas and petroleum and vice versa. Looser priors lead to serial correlation in the equation for coal. The variance decompositions of a model that includes the real price of coal also show that coal consumption is independent of price. For this reason, the price of coal was dropped from the model. The independent behaviour of coal may be explained by the fact that coal is now mostly used for electricity generation by the State government.

The variance decompositions of the final model indicate that natural gas substitutes for petroleum. Natural gas consumption depends on real GDP while petroleum consumption is moved by the real price of oil and consumption of natural gas. As in model 1, the real price of oil and real GDP are exogenous. The impulse responses display the expected signs. A positive shock to natural gas has a negative impact on petroleum for five years, a shock to the price of oil reduces petroleum consumption, and a shock to real GDP leads to an expansion in natural gas. 
THE PRIOR IS....

TIGHTNESS PARAMETER 0.40000

HARMONIC LAG DECAY WITH PARAMETER

MEANS AND STANDARD DEVIATIONS AS PERCENTAGE OE OWN LAG LISTED UNDER THE DEPENDENT VARIABLE

RGDP

NGAS

PETR

COAL

PRIC

1. 00000000

0.50000000

0.50000000

0.50000000

0.50000000

RGDP

1.00000000

0.50000000

0.50000000

NGAS $\quad 0.50000000$

0.50000000

1. 0.0000000

0.50000000

0.50000000

0.50000000

0.50000000

1. .00000000

COAL $\quad 0.50000000$

0.50000000

0.10000000

0.10000000

0.50000000

1.00000000

1. 00000000

1.00000000

I. 00000000

0.10000000

0.10000000

1.00000000

1.00000000 
EQUATION 1

DEPENDENT VARIABLE 10

FROM 1967: 1 UNTIL

TOTAL OBSERVATIONS 25

USABLE OBSERVATIONS 25

$R * * 2$

.90710955

$\mathrm{SSR}$

11.746955

DURBIN-WATSON 1.99125960

Q $(12)=9.63028$

NO.

1

2

3

4

5

6

7

8

$\dot{9}$

11

12

13

14

15

16

17

18

19

20

21

22

23

24

25

26

27

28

29

30

31

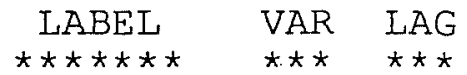

PRIC

PRIC

PRIC

PRIC

PRIC

PRIC

RGDP

RGDP

RGDP

RGDP

RGDP

RGDP

NGAS

NGAS

NGAS

NGAS

NGAS

NGAS

PETR

PETR

PETR

PETR

PETR

PETR

COAI

COAL

COAL

COAL

COAL

COAL

CONSTANT

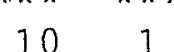

$10 \quad 2$

103

104

105

106

$6-2$

64

6

6

9

9

9

9

9

9

8

8

8

8

8

8

7

7

7

7

7

7

0
6
1991: 1

SKIPPED/MISSING

DEGREES OF FREEDOM 24

$\mathrm{RBAR}^{*} * 2 \quad .90710955$

SEE .69961166

SIGNIFICANCE LEVEL . 648360

COEFEICIENT STAND. ERROR

.7559875

.1529940

.1360471

.1013906

$.8199398 \mathrm{E}-01$

$.7130856 \mathrm{E}-01$

$.6092206 \mathrm{E}-01$

4. 381820

3. 446551

2.439774

1.880439

1.525072

1. 278001

.1290268

$.8161425 \mathrm{E}-01$

$.5699536 \mathrm{E}-01$

$.4399435 \mathrm{E}-01$

$.3568816 \mathrm{E}-01$

$.2994834 \mathrm{E}-01$

.2440789

.1802123

.1281311

$.9928251 \mathrm{E}-01$

$.8060583 \mathrm{E}-01$

$.6773801 \mathrm{E}-01$

.2492162

.1659382

.1151863

$.8758653 \mathrm{E}-01$

$.7092002 \mathrm{E}-01$

$.5952165 E-01$

37.35643
T-STATISTIC

4. 941289

$-.9393115$

$.9960756 \mathrm{E}-01$

$-.2500343$

.2967883

$-.5845470 \mathrm{E}-01$

$-.3076171$

$-.6281967$

$-.3163665 \mathrm{E}-02$

.3885265

-.3445575E-01

.1258503

$-.5481068$

.2522620

.1549125

$-.8907732 \mathrm{E}-03$

.1985362

.2568155

1. 107942

.4290919

.5856294

.4586707

.1584013

.3209350

1.615727

$-.3581582$

.1679729

.2917557

.2752427

-. $3849913 \mathrm{E}-01$

.6689258 


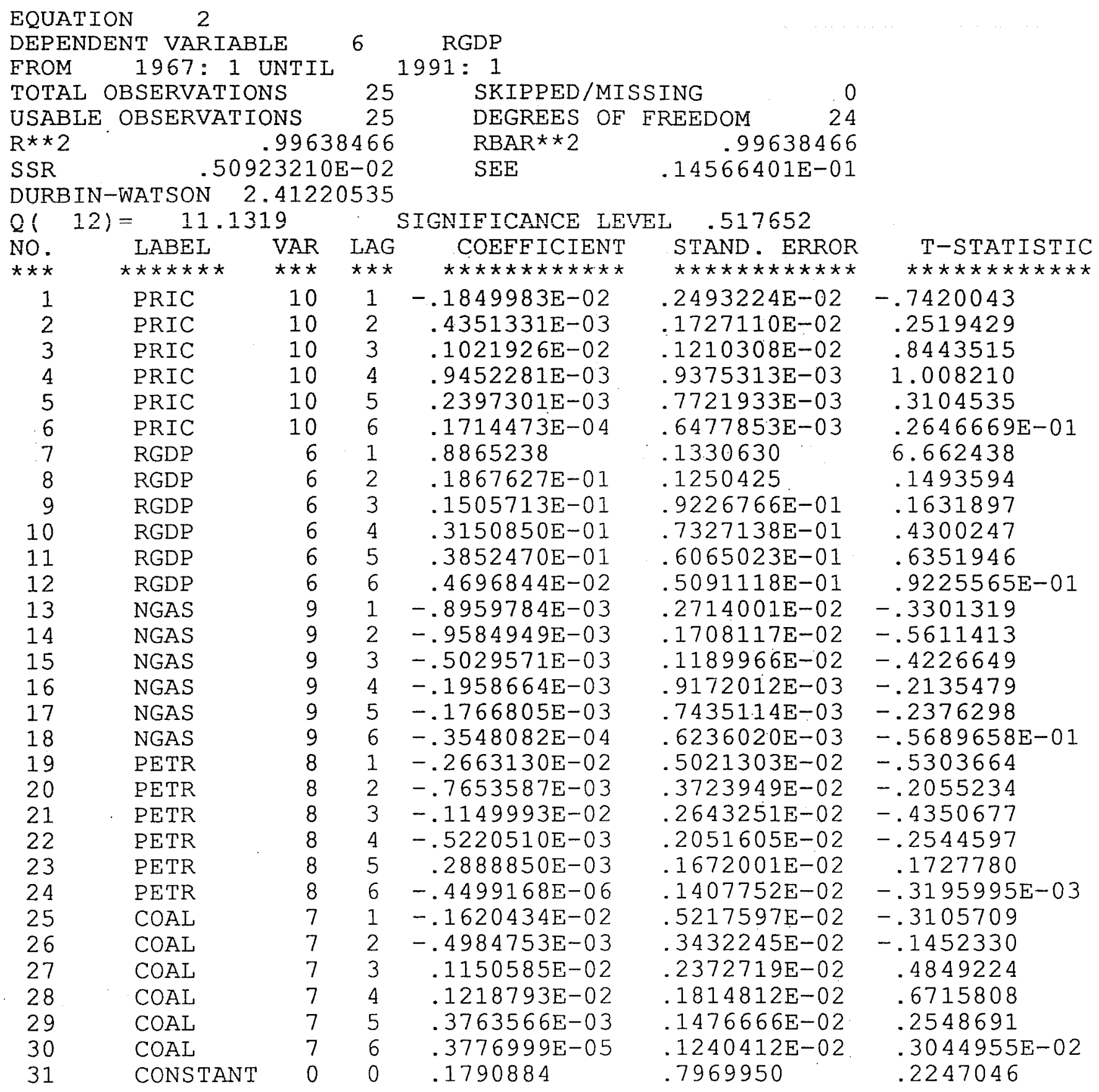




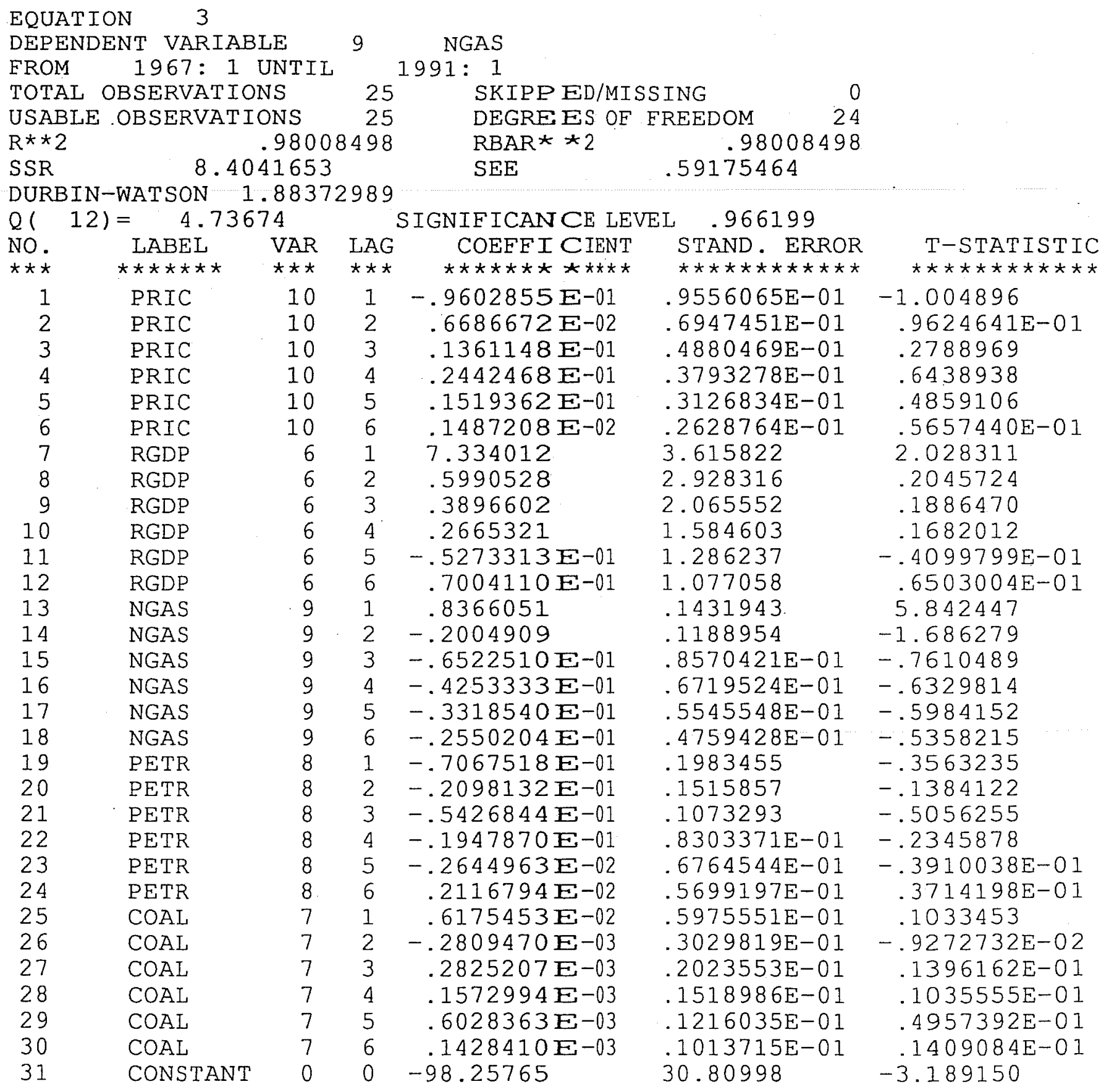




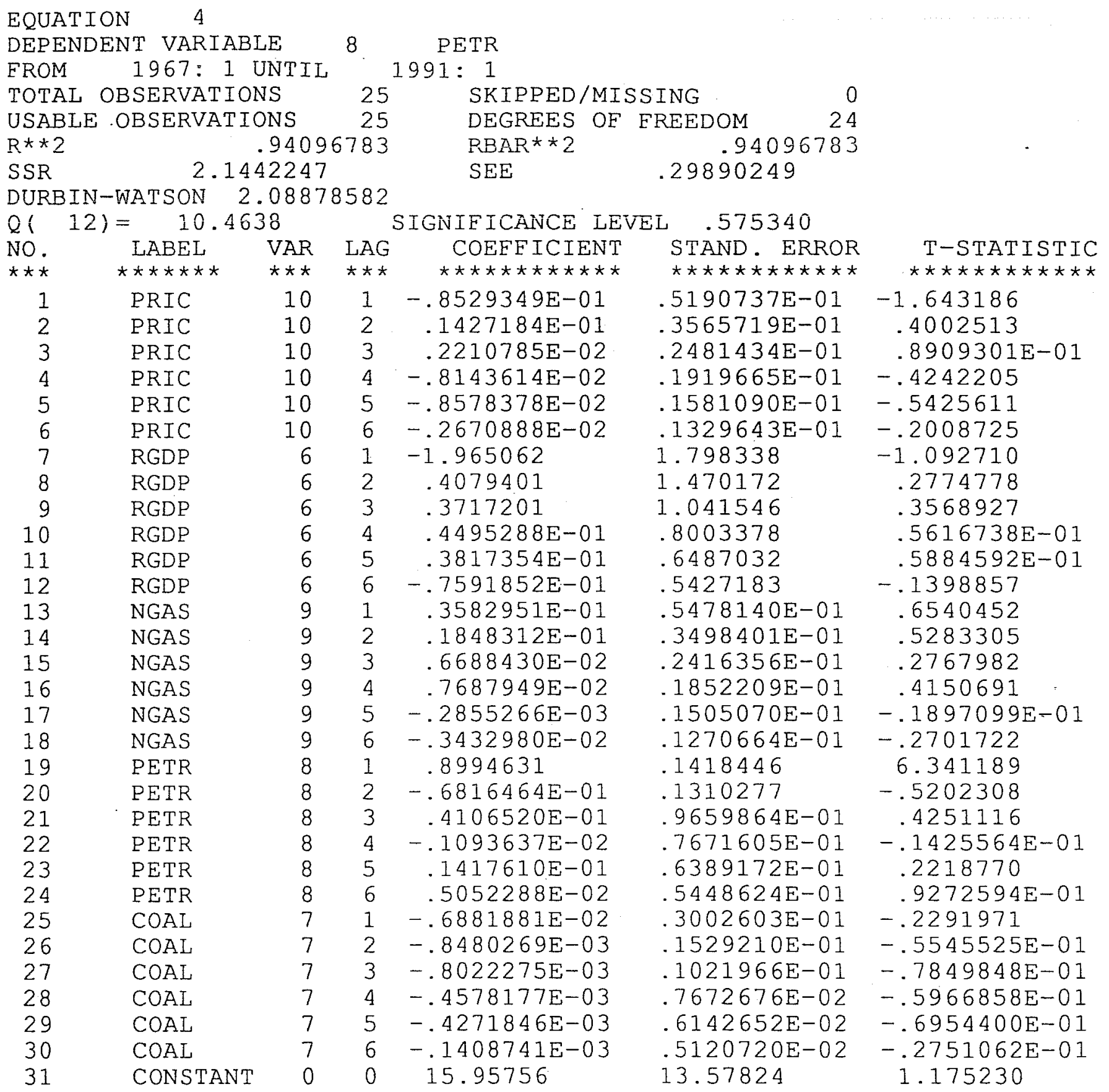




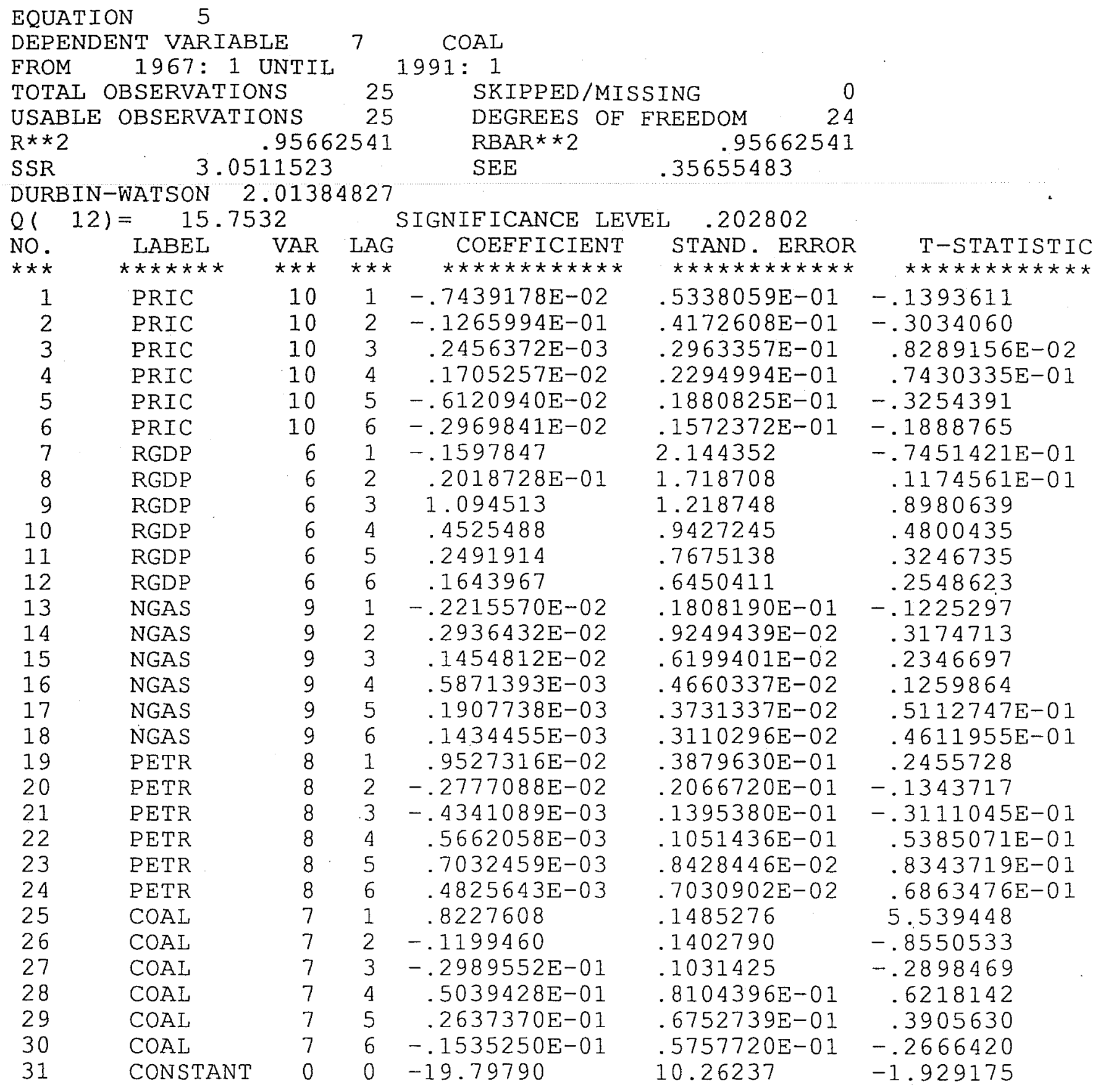


RESPONSES TO ONE-STANDARD DEVIATION SHOCK IN

PRIC

\begin{tabular}{rllll} 
ENTRY & \multicolumn{1}{l}{ PRIC } & \multicolumn{1}{l}{ RGDP } & COAL & NGAS \\
.1 & .685477 & $-.179219 \mathrm{E}-02$ & $.918924 \mathrm{E}-01$ & $-.346892 \mathrm{E}-01$ \\
2 & .535499 & $-.273267 \mathrm{E}-02$ & $.700032 \mathrm{E}-01$ & -.100998 \\
3 & .309445 & $-.274529 \mathrm{E}-02$ & $.333665 \mathrm{E}-01$ & -.133387 \\
4 & .140833 & $-.127806 \mathrm{E}-02$ & $.471829 \mathrm{E}-02$ & -.109380 \\
5 & $.420303 \mathrm{E}-02$ & $.974675 \mathrm{E}-03$ & $-.624745 \mathrm{E}-02$ & $-.332034 \mathrm{E}-01$ \\
6 & $-.808161 \mathrm{E}-01$ & $.282654 \mathrm{E}-02$ & $-.122541 \mathrm{E}-01$ & $.666235 \mathrm{E}-01$ \\
7 & -.150524 & $.393758 \mathrm{E}-02$ & $-.172915 \mathrm{E}-01$ & .151376 \\
8 & -.204751 & $.447796 \mathrm{E}-02$ & $-.162589 \mathrm{E}-01$ & .205063 \\
9 & -.234121 & $.464640 \mathrm{E}-02$ & $-.879652 \mathrm{E}-02$ & .224555 \\
10 & -.236002 & $.453228 \mathrm{E}-02$ & $.268259 \mathrm{E}-02$ & .213591 \\
11 & -.212700 & $.416071 \mathrm{E}-02$ & $.145578 \mathrm{E}-01$ & .179686 \\
12 & -.171344 & $.358842 \mathrm{E}-02$ & $.245833 \mathrm{E}-01$ & .131958
\end{tabular}

\begin{tabular}{|c|c|c|}
\hline \multicolumn{3}{|l|}{ ENTRY } \\
\hline & 1 & $-.909056 E-01$ \\
\hline & 2 & -.138586 \\
\hline & 3 & -.154529 \\
\hline & 4 & -.154142 \\
\hline & 5 & -.152888 \\
\hline & 6 & -.150976 \\
\hline & 7 & -.141172 \\
\hline & 8 & -.119318 \\
\hline & 9 & $-.886111 E-01$ \\
\hline & 10 & $-.549249 E-01$ \\
\hline & 1 & $-.234632 E-01$ \\
\hline & 12 & $.244848 E-02$ \\
\hline
\end{tabular}


ENTRY

$\begin{array}{rl} & \text { PRIC } \\ 1 & .000000 \\ 2 & -.312945 \mathrm{E}-01 \\ 3 & -.893713 \mathrm{E}-01 \\ 4 & -.126355 \\ 5 & -.123441 \\ 6 & -.103245 \\ 7 & -.691986 \mathrm{E}-01 \\ 8 & -.321911 \mathrm{E}-01 \\ 9 & .323251 \mathrm{E}-02 \\ 10 & .345397 \mathrm{E}-01 \\ 11 & .581379 \mathrm{E}-01 \\ 12 & .719051 \mathrm{E}-01\end{array}$

ENTRY
RGDP

.141591E-01 $.124744 \mathrm{E}-01$ $.112214 \mathrm{E}-01$ $.101637 \mathrm{E}-01$

$.940300 \mathrm{E}-02$

$.892169 \mathrm{E}-02$

$.820326 \mathrm{E}-02$

$.736325 \mathrm{E}-02$

$.656882 \mathrm{E}-02$

$.591553 \mathrm{E}-02$

$.543487 \mathrm{E}-02$

$.511214 \mathrm{E}-02$
COAL

$-.390895 E-01$

$-.342808 E-01$

$-.252058 \mathrm{E}-01$

$-.473575 \mathrm{E}-03$

$.228170 E-01$

$.401940 \mathrm{E}-01$

$.525349 E-01$

$.594926 \mathrm{E}-01$

$.633795 E-01$

$.645351 \mathrm{E}-01$

$.632207 \mathrm{E}-01$

$.598781 \mathrm{E}-01$
NGAS

$.669371 \mathrm{E}-01$

.157442

.220264

.250768

.252974

.228528

.188935

.141861

$.970319 \mathrm{E}-01$

$.618091 \mathrm{E}-01$

$.396891 \mathrm{E}-01$

$.310097 \mathrm{E}-01$

$\begin{array}{ll} & \text { PETR } \\ 1 & .305621 \mathrm{E}-01 \\ 2 & .233322 \mathrm{E}-02 \\ 3 & -.890492 \mathrm{E}-02 \\ 4 & .474068 \mathrm{E}-04 \\ 5 & .147171 \mathrm{E}-01 \\ 6 & .292826 \mathrm{E}-01 \\ 7 & .389796 \mathrm{E}-01 \\ 8 & .441545 \mathrm{E}-01 \\ 9 & .449380 \mathrm{E}-01 \\ 0 & .412996 \mathrm{E}-01 \\ 1 & .338256 \mathrm{E}-01 \\ 12 & .237917 \mathrm{E}-0.1\end{array}$


RESPONSES TO ONE-STANDARD DEVIATION SHOCK IN

COAL

\begin{tabular}{cllll} 
ENTRY & \multicolumn{1}{l}{ PRIC } & RGDP & COAL & NGAS \\
.1 & .000000 & .000000 & .334774 & $-.907998 \mathrm{E}-01$ \\
2 & .142546 & $-.474151 \mathrm{E}-03$ & .275687 & $-.742418 \mathrm{E}-01$ \\
3 & .202962 & $-.114477 \mathrm{E}-02$ & .185558 & $-.594849 \mathrm{E}-01$ \\
4 & .199584 & $-.117379 \mathrm{E}-02$ & .106054 & $-.539016 \mathrm{E}-01$ \\
5 & .166864 & $-.473677 \mathrm{E}-03$ & $.687515 \mathrm{E}-01$ & $-.461627 \mathrm{E}-01$ \\
6 & .124747 & $.492552 \mathrm{E}-03$ & $.555724 \mathrm{E}-01$ & $-.250128 \mathrm{E}-01$ \\
7 & $.790739 \mathrm{E}-01$ & $.132329 \mathrm{E}-02$ & $.396219 \mathrm{E}-01$ & $.884019 \mathrm{E}-02$ \\
8 & $.305696 \mathrm{E}-01$ & $.195168 \mathrm{E}-02$ & $.241217 \mathrm{E}-01$ & $.445343 \mathrm{E}-01$ \\
9 & $-.154057 \mathrm{E}-01$ & $.244571 \mathrm{E}-02$ & $.129918 \mathrm{E}-01$ & $.750372 \mathrm{E}-01$ \\
10 & $-.527413 \mathrm{E}-01$ & $.283578 \mathrm{E}-02$ & $.838562 \mathrm{E}-02$ & $.968224 \mathrm{E}-01$ \\
11 & $-.778102 \mathrm{E}-01$ & $.309122 \mathrm{E}-02$ & $.847162 \mathrm{E}-02$ & .108469 \\
12 & $-.901203 \mathrm{E}-01$ & $.318240 \mathrm{E}-02$ & $.107378 \mathrm{E}-01$ & .109816
\end{tabular}

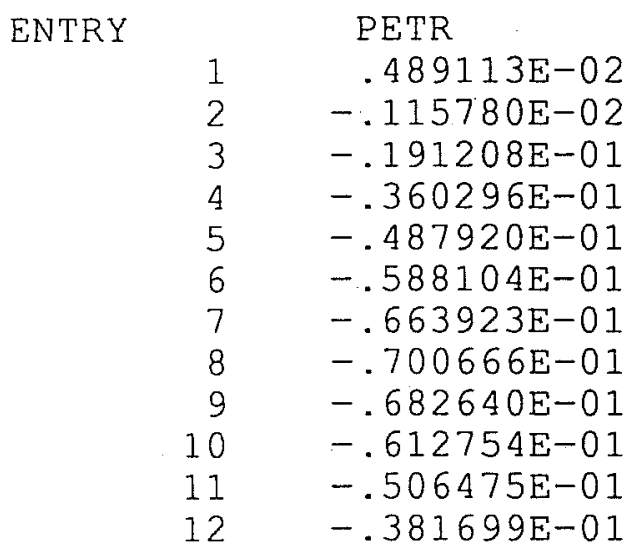


RESPONSES TO ONE-STANDARD DEVIATION SHOCK IN NGAS

\begin{tabular}{cllll} 
ENTRY & \multicolumn{1}{l}{ PRIC } & RGDP & COAL & NGAS \\
.1 & .000000 & .000000 & .000000 & .567660 \\
2 & $-.899309 \mathrm{E}-01$ & $-.183244 \mathrm{E}-04$ & $-.301169 \mathrm{E}-02$ & .487919 \\
3 & -.145510 & $-.298525 \mathrm{E}-03$ & $-.209269 \mathrm{E}-02$ & .316996 \\
4 & -.153423 & $-.524910 \mathrm{E}-03$ & $.216228 \mathrm{E}-02$ & .160373 \\
5 & -.131895 & $-.730864 \mathrm{E}-03$ & $.660375 \mathrm{E}-02$ & $.388918 \mathrm{E}-01$ \\
6 & $-.861778 \mathrm{E}-01$ & $-.113217 \mathrm{E}-02$ & $.874059 \mathrm{E}-02$ & $-.495317 \mathrm{E}-01$ \\
7 & $-.374030 \mathrm{E}-01$ & $-.150862 \mathrm{E}-02$ & $.892852 \mathrm{E}-02$ & -.109981 \\
8 & $.267177 \mathrm{E}-02$ & $-.173627 \mathrm{E}-02$ & $.790624 \mathrm{E}-02$ & -.132366 \\
9 & $.288044 \mathrm{E}-01$ & $-.178294 \mathrm{E}-02$ & $.569048 \mathrm{E}-02$ & -.124598 \\
10 & $.397387 \mathrm{E}-01$ & $-.167243 \mathrm{E}-02$ & $.247442 \mathrm{E}-02$ & $-.987124 \mathrm{E}-01$ \\
11 & $.381829 \mathrm{E}-01$ & $-.146472 \mathrm{E}-02$ & $-.127483 \mathrm{E}-02$ & $-.655074 \mathrm{E}-01$ \\
12 & $.280978 \mathrm{E}-01$ & $-.121810 \mathrm{E}-02$ & $-.487676 \mathrm{E}-02$ & $-.332077 \mathrm{E}-01$
\end{tabular}

\begin{tabular}{|c|c|c|}
\hline \multirow{13}{*}{ ENTRY } & & PETR \\
\hline & 1 & -.184102 \\
\hline & 2 & -.145254 \\
\hline & 3 & $-.823999 \mathrm{E}-01$ \\
\hline & 4 & $-.358781 \mathrm{E}-01$ \\
\hline & 5 & $-.148243 E-02$ \\
\hline & 6 & $.158813 \mathrm{E}-01$ \\
\hline & 7 & $.191164 \mathrm{E}-01$ \\
\hline & 8 & $.155899 \mathrm{E}-01$ \\
\hline & 9 & $.860602 E-02$ \\
\hline & 10 & $.531665 E-03$ \\
\hline & 11 & $-.671659 E-02$ \\
\hline & 12 & $-.118308 E-01$ \\
\hline
\end{tabular}


ENTRY

$\begin{array}{rl} & \text { PRIC } \\ .1 & .000000 \\ 2 & .558503 \mathrm{E}-01 \\ 3 & .110994 \\ 4 & .153085 \\ 5 & .180012 \\ 6 & .186672 \\ 7 & .180918 \\ 8 & .161006 \\ 9 & .130134 \\ 10 & .933965 \mathrm{E}-01 \\ 11 & .553220 \mathrm{E}-01 \\ 12 & .201844 \mathrm{E}-01\end{array}$

ENTRY

$\begin{array}{rl} & \text { PETR } \\ 1 & .206528 \\ 2 & .185764 \\ 3 & .148791 \\ 4 & .121492 \\ 5 & .949241 \mathrm{E}-01 \\ 6 & .707967 \mathrm{E}-01 \\ 7 & .476640 \mathrm{E}-01 \\ 8 & .252115 \mathrm{E}-01 \\ 9 & .565498 \mathrm{E}-02 \\ 10 & -.926765 \mathrm{E}-02 \\ 11 & -.188712 \mathrm{E}-01 \\ 12 & -.233048 \mathrm{E}-01\end{array}$

$$
\begin{aligned}
& \text { RGDP } \\
& .000000 \\
& -.550011 \mathrm{E}-03 \\
& -.123381 \mathrm{E}-02 \\
& -.201712 \mathrm{E}-02 \\
& -.264543 \mathrm{E}-02 \\
& -.287469 \mathrm{E}-02 \\
& -.282409 \mathrm{E}-02 \\
& -.258281 \mathrm{E}-02 \\
& -.221990 \mathrm{E}-02 \\
& -.179553 \mathrm{E}-02 \\
& -.136145 \mathrm{E}-02 \\
& -.968733 \mathrm{E}-03
\end{aligned}
$$

COAL

$$
.000000
$$$$
.196766 \mathrm{E}-02
$$$$
.251994 \mathrm{E}-02
$$$$
.134629 \mathrm{E}-02
$$$$
-.127742 \mathrm{E}-02
$$$$
-.485268 \mathrm{E}-02
$$$$
-.947648 \mathrm{E}-02
$$$$
-.149566 \mathrm{E}-01
$$$$
-.202962 \mathrm{E}-01
$$$$
-.245097 \mathrm{E}-01
$$$$
-.269675 \mathrm{E}-01
$$

$-.275418 \mathrm{E}-01$
NGAS

.000000

$-.145964 \mathrm{E}-01$

$-.390584 \mathrm{E}-01$

$-.750198 \mathrm{E}-01$

$-.108728$

$-.128883$

$-.130387$

$-.115862$

$-.901041 E-01$

$-.587898 \mathrm{E}-01$

$-.275425 E-01$

-.880813E-03 
DECOMPOSITION OF VARIANCE, SERIES

\section{STEP}

1

3

4

5

6

7

8

9

10

11

12

STEP

1

2

3

4

5

6

8

9

10

11

12
STAN ERR

.685477

.888337

.983653

1.04412

1.08769

1. 12165

1. 15149

1. 18142

1. 21185

1. 24039

1. 26402

1. 28125

PETR

.000000

.395271

1. 595628

3.565819

6.024798

8. 435264

10.472291

11.805676

12.373392

12.377603

12.110585

11.811924
PRIC

100.0000000

95.8809048

88.0961021

80.0077101

73.7266969

69.8492400

67.9848654

67.5874667

67.9682507

68.4971294

68.7909752

68.7419725

\begin{tabular}{rlc}
\multicolumn{3}{l}{ DECOMPOSITION OF VARIANCE, SERIES } \\
STEP & STAN ERR & PRIC \\
1 & $.142721 \mathrm{E}-01$ & 1.5768559 \\
2 & $.191650 \mathrm{E}-01$ & 2.9075634 \\
3 & $.224427 \mathrm{E}-01$ & 3.6166200 \\
4 & $.247857 \mathrm{E}-01$ & 3.2310651 \\
5 & $.266731 \mathrm{E}-01$ & 2.9235095 \\
6 & $.284399 \mathrm{E}-01$ & 3.5593160 \\
7 & $.300604 \mathrm{E}-01$ & 4.9017065 \\
8 & $.314864 \mathrm{E}-01$ & 6.4903928 \\
9 & $.327142 \mathrm{E}-01$ & 8.0295915 \\
10 & $.337612 \mathrm{E}-01$ & 9.3414812 \\
11 & $.346442 \mathrm{E}-01$ & 10.3137088 \\
12 & $.353806 \mathrm{E}-01$ & 10.9175642
\end{tabular}

STEP

1

2

3

4

5

6

7

8

9

10

11

12 PETR

.000000

.082361

.362297

.959346

1. 812044

2. 615597

3. 223796

3. 611286

3. 805761

3.856226

3.816586

3.734350
11 PRIC

RGDP

.0000000

.1241 .021

.9267081

2.2869835

3.3953727

4.0401605

4.1946220

4.0590275

3.8584568

3.7605133

3.8327407

4.0453238
COAL

.0000000

2.5748671

6.3574308

9. 2963080

10.9198229

11.5055495

11.3885449

10.8857785

10.3621271

10.0716521

10.0774485

10.3030171
NGAS

.0000000

1.0248545

3. 0241314

4. 8431795

5.9333096

6.1697860

5. 9596766

5. 6620512

5. 4377734

5.2931024

5.1882508

5.0977630
8 RGDP

RGDP

98.4231441

96.9487749

95.6984988

95.2759886

94.6970723

93.1375469

90.8134384

88.2429022

85.7752241

83.6078568

81.8611303

80.5770307
COAL

.0000000

.0612089

.3048239

.4741892

.4409927

.4178969

.5678390

.9017810

1. 3942635

2. 0146492

2. 7094131

3. 4068725
NGAS

.0000000

.0000914

.0177600

.0594114

.1263811

.2696429

.4932199

.7536379

.9951599

1.1797870

1. 2991618

1. 3641823 
DECOMPOSITION OF VARIANCE, SERIES

$\begin{array}{rc}\text { STEP } & \text { STAN ERR } \\ 1 & .349351 \\ 2 & .451816 \\ 3 & .490234 \\ 4 & .501603 \\ 5 & .506890 \\ 6 & .511753 \\ 7 & .516420 \\ 8 & .520924 \\ 9 & .525422 \\ 10 & .530017 \\ 11 & .534722 \\ 12 & .539458 \\ & \\ \text { STEP } & \text { PETR } \\ 1 & .000000 \\ 2 & .001897 \\ 3 & .004253 \\ 4 & .004783 \\ 5 & .005319 \\ 6 & .014210 \\ 7 & .047628 \\ 8 & .129244 \\ 9 & .276256 \\ 10 & .485331 \\ 11 & .731175 \\ 12 & .979050\end{array}$

DECOMPOSITION OF VARIANCE， SERIES

$\begin{array}{rc}\text { STEP } & \text { STAN ERR } \\ 1 & .579799 \\ 2 & .784184 \\ 3 & .887020 \\ 4 & .946523 \\ 5 & .988164 \\ 6 & 1.02607 \\ 7 & 1.06799 \\ 8 & 1.11163 \\ 9 & 1.15101 \\ 10 & 1.18188 \\ 11 & 1.20313 \\ 12 & 1.21617 \\ \text { STEP } & \text { PETR } \\ 1 & .000000 \\ 2 & .034646 \\ 3 & .220972 \\ 4 & .822250 \\ 5 & 1.965083 \\ 6 & 3.400313 \\ 7 & 4.629117 \\ 8 & 5.359180 \\ 9 & 5.611513 \\ 10 & 5.569635 \\ 11 & 5.427048 \\ 12 & 5.311381\end{array}$

PRIC

6.9188707

6.5370783

6.0159065

5.7551362

5.6509031

5.6013479

5.6126812

5.6134694

5.5457789

5.4526105

5.4312014

5.5439222

3

COAL

RGDP

1.2519762

1. 3241847

1. 3891344

1. 3269659

1. 5.020537

2.0905211

3. 0877866

4. 3389300

5.7200032

7.1038283

8.3772281

9. 4628125
COAL

91.8291531

92.1323972

92.5851096

92.9059112

92.8176973

92.2411769

91.1702173

89.8150406

88.3446785

86.8447224

85.3483080

83.8959150
NGAS

.0000000

.0044432

.0055963

.0072038

.0240271

.0527442

.0816871

.1033159

.1132838

.1135078

.1120876

.1183005
$9 \quad$ NGAS

\section{RGDP}

1. 3328427

4.7595282

9.8861597

15.7013493

20.9597208

24.4001523

25.6518201

25.3061627

24.3146277

23.3345515

22.6264307

22.2089880
COAL

2. 4525328

2.2370213

2. 1981207

2. 2547346

2. 2869420

2.1805115

2. 0195417

2.0246115

2. 3134319

2.8652855

3.5777792

4. 3168408
NGAS

95.8566642

91.1143321

83.9840274

76.6274314

70.4601641

65.5832198

61.5961318

58.2734092

55.5254925

53.3603781

51.7886831

50.7589647 


\begin{tabular}{rccrrl}
\multicolumn{1}{l}{ DECOMPOSITION OE VARIANCE, SERIES } & \multicolumn{1}{l}{ IO } & PETR \\
STEP & STAN ERR & PRIC & RGDP & COAL & \multicolumn{1}{l}{ NGAS } \\
1 & .292863 & 9.6349754 & 1.0890178 & .0278926 & 39.5171311 \\
2 & .400736 & 17.1057950 & .5850237 & .0157319 & 34.2440041 \\
3 & .462430 & 24.0127791 & .4764186 & .1827837 & 28.8914002 \\
4 & .504923 & 29.4606776 & .3996056 & .6624906 & 24.7380889 \\
5 & .538453 & 33.9679499 & .4260922 & 1.4036588 & 21.7538095 \\
6 & .567720 & 37.6281097 & .6493352 & 2.3357642 & 19.6469816 \\
7 & .592284 & 40.2529009 & 1.0297189 & 3.4025754 & 18.1552984 \\
8 & .610553 & 41.6991920 & 1.4920201 & 4.5189693 & 17.1502794 \\
9 & .622425 & 42.1504583 & 1.9569081 & 5.5510790 & 16.5214178 \\
10 & .629266 & 42.0007758 & 2.3453356 & 6.3792423 & 16.1642023 \\
11 & .632959 & 41.6495412 & 2.6036383 & 6.9452970 & 15.9874048 \\
12 & .635097 & 41.3709818 & 2.7264684 & 7.2598088 & 15.9146090
\end{tabular}

$\begin{array}{rl}\text { STEP } & \text { PETR } \\ 1 & 49.730983 \\ 2 & 48.049445 \\ 3 & 46.436618 \\ 4 & 44.739137 \\ 5 & 42.448490 \\ 6 & 39.739809 \\ 7 & 37.159506 \\ 8 & 35.139539 \\ 9 & 33.820137 \\ 10 & 33.110444 \\ 11 & 32.814119 \\ 12 & 32.728132\end{array}$


Appendix 5.

Model 3: Petroleum Products 
In this model the consumption of petroleum products is split into automotive gasoline and automotive distillate. The variables used for modelling are the real price of oil, real GDP, automotive gasoline consumption and automotive distillate consumption. To maintain consistency with model 2 , the fuels are transformed into square root form, and real GDP is logarithmic. A standard symmetric prior is applied. The Q-values indicate that serial correlation is not a problem.

This model displays the most complex variance decompositions and impulse responses. Automotive distillate consumption depends on all other variables in the model, automotive gasoline consumption is somewhat influenced by real GDP, and the real price of oil is related to automotive gasoline consumption. As in the other models, real GDP is exogenous. The impulse responses display negative price effects and positive income effects, and the effect of automotive gasoline consumption on the real price of oil is positive. 
THE PRIOR IS....

TIGHTNESS PARAMETER 0.40000

HARMONIC LAG DECAY WITH PARAMETER

1.00000

MEANS AND STANDARD DEVIATIONS AS PERCENTAGE OF OWN LAG LISTED UNDER THE DEPENDENT VARIABLE

$\begin{array}{llccc} & \text { RGDP } & \text { PRIC } & \text { AGAS } & \text { ADIS } \\ \text { RGDP } & 1.00000000 & 0.50000000 & 0.50000000 & 0.50000000 \\ \text { PRIC } & 0.50000000 & 1.00000000 & 0.50000000 & 0.50000000 \\ \text { AGAS } & 0.50000000 & 0.50000000 & 1.00000000 & 0.50000000 \\ \text { ADIS } & 0.50000000 & 0.50000000 & 0.50000000 & 1.00000000 \\ \text { MEAN } & 1.00000000 & 1.00000000 & 1.00000000 & 1.00000000\end{array}$




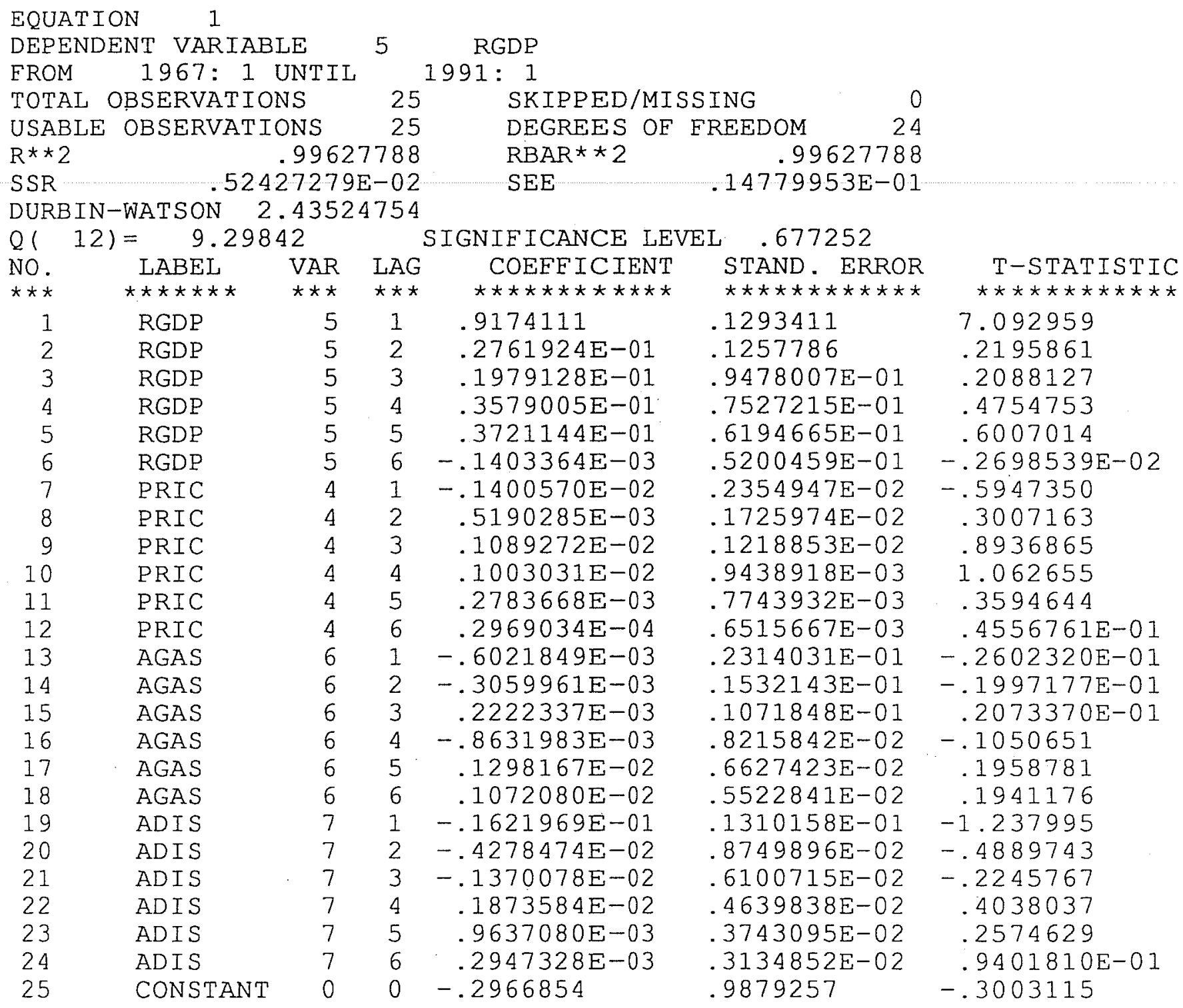




\begin{tabular}{|c|c|c|c|c|c|c|}
\hline \multicolumn{7}{|c|}{ EQUATION 2} \\
\hline DEPE & ENT VARIAB & & 4 & PRIC & & \\
\hline \multicolumn{7}{|c|}{ EROM 1967: 1 UNTIL } \\
\hline \multicolumn{3}{|c|}{ TOTAL OBSERVATIONS } & 25 & \multicolumn{2}{|c|}{ SKIPPED/MISSING } & \\
\hline USAE & OBSERVATI & DNS & 25 & DEGREES OF & FREEDOM & \\
\hline$R * * 2$ & & .90311 & 1484 & $R B A R * * 2$ & .90311484 & \\
\hline SSR & 12.2 & 52127 & & SEE & .71449654 & \\
\hline \multicolumn{7}{|c|}{ DURBIN-WATSON $\quad 2.19571861$} \\
\hline Qi & $j=11.54$ & & & SIGNIFICANCE LE & .483215 & \\
\hline \multirow{2}{*}{$\begin{array}{l}\text { NO. } \\
\star \star *\end{array}$} & LABEL & VAR & LAG & COEFEICIENT & STAND. ERROR & T-STATISTIC \\
\hline & 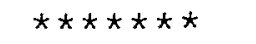 & $\star \star \star$ & $\star \star \star \star$ & 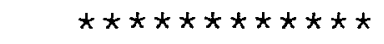 & 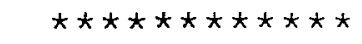 & 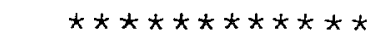 \\
\hline 1 & RGDP & 5 & 1 & -5.620638 & 4.561364 & -1.232227 \\
\hline 2 & RGDP & 5 & 2 & -4.132813 & 3.533012 & -1.169771 \\
\hline 3 & RGDP & 5 & 3 & -1.014690 & 2.521293 & -.4024482 \\
\hline 4 & RGDP & 5 & 4 & .3159611 & 1.937678 & .1630617 \\
\hline 5 & RGDP & 5 & 5 & -.2834280 & 1.564673 & -.1811420 \\
\hline 6 & RGDP & 5 & 6 & $.3068348 E-01$ & 1.309827 & $.2342560 E-01$ \\
\hline 7 & PRIC & 4 & 1 & .7965809 & .1447050 & 5.504860 \\
\hline 8 & PRIC & 4 & 2 & -.1287226 & .1370952 & -.9389288 \\
\hline 9 & PRIC & 4 & 3 & $.7573778 \mathrm{E}-02$ & .1027292 & $.7372566 \mathrm{E}-01$ \\
\hline 10 & PRIC & 4 & 4 & $-.2251612 \mathrm{E}-01$ & $.8260740 \mathrm{E}-01$ & -.2725678 \\
\hline 11 & PRIC & 4 & 5 & $.1634280 \mathrm{E}-01$ & $.7020538 \mathrm{E}-01$ & .2327855 \\
\hline 12 & PRIC & 4 & 6 & $-.1908127 \mathrm{E}-01$ & $.6017802 \mathrm{E}-01$ & -.3170803 \\
\hline 13 & AGAS & 6 & 1 & .3588521 & 1.112297 & .3226225 \\
\hline 14 & AGAS & 6 & 2 & .4587873 & .7395750 & .6203390 \\
\hline 15 & AGAS & 6 & 3 & .3741253 & .5191738 & .7206166 \\
\hline 16 & AGAS & 6 & 4 & .1620305 & .3985511 & .4065490 \\
\hline 17 & AGAS & 6 & 5 & $.3030846 \mathrm{E}-01$ & .3213243 & $.9432357 \mathrm{E}-01$ \\
\hline 18 & AGAS & 6 & 6 & $.5667780 \mathrm{E}-01$ & .2680346 & .2114570 \\
\hline 19 & ADIS & 7 & 1 & .8844373 & .6415114 & 1.378677 \\
\hline 20 & ADIS & 7 & 2 & $.8199796 \mathrm{E}-01$ & .4242715 & .1932676 \\
\hline 21 & ADIS & 7 & 3 & $.9037646 \mathrm{E}-01$ & .2958447 & .3054861 \\
\hline 22 & $\mathrm{ADIS}$ & 7 & 4 & $.3111713 \mathrm{E}-01$ & .2249631 & .1383210 \\
\hline 23 & ADIS & 7 & 5 & $.4465688 \mathrm{E}-01$ & .1815069 & .2460341 \\
\hline 24 & ADIS & 7 & 6 & $.2425843 E-01$ & .1519839 & .1596119 \\
\hline 25 & CONSTANT & 0 & 0 & 114.1583 & 46.68484 & 2.445296 \\
\hline
\end{tabular}




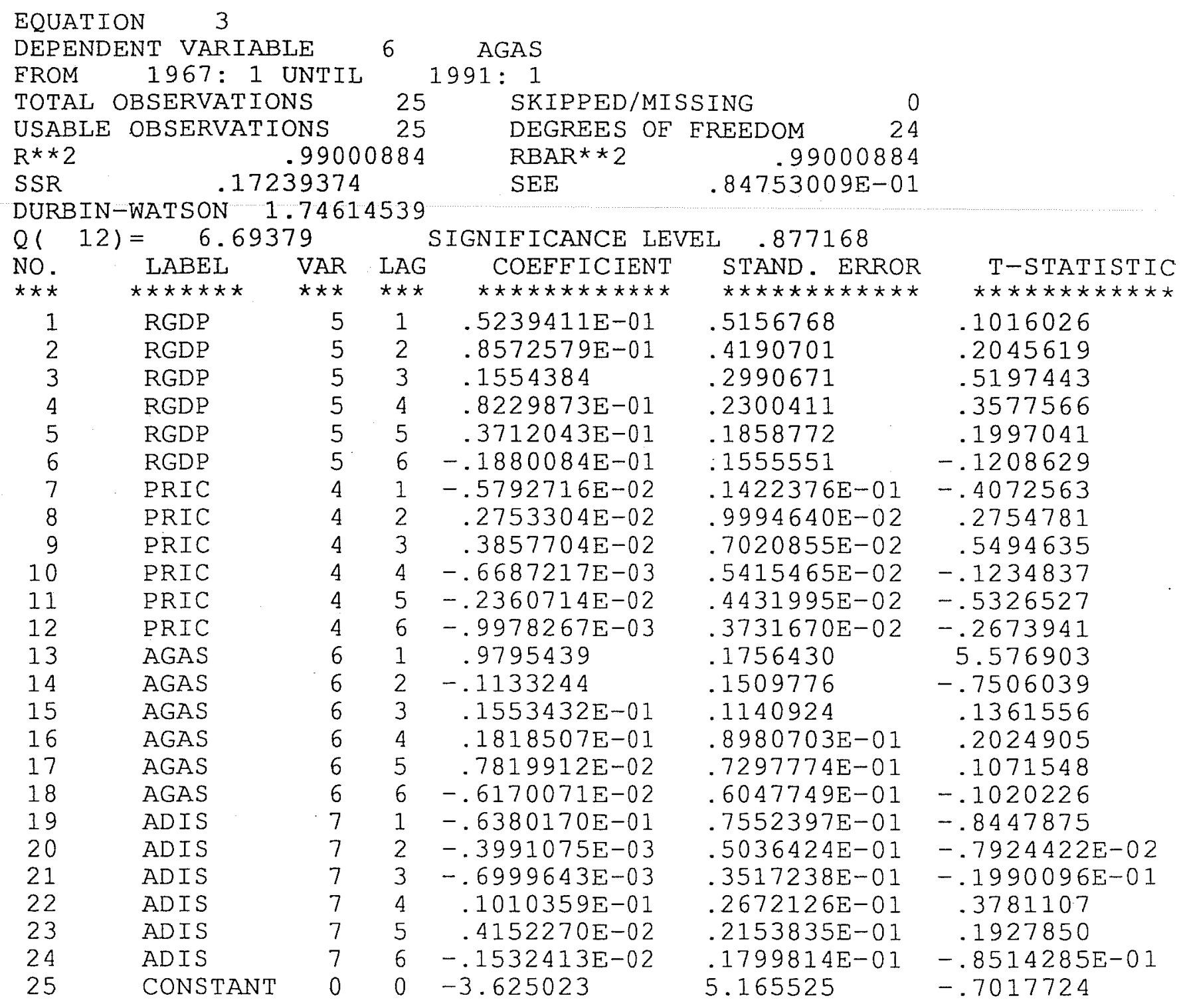




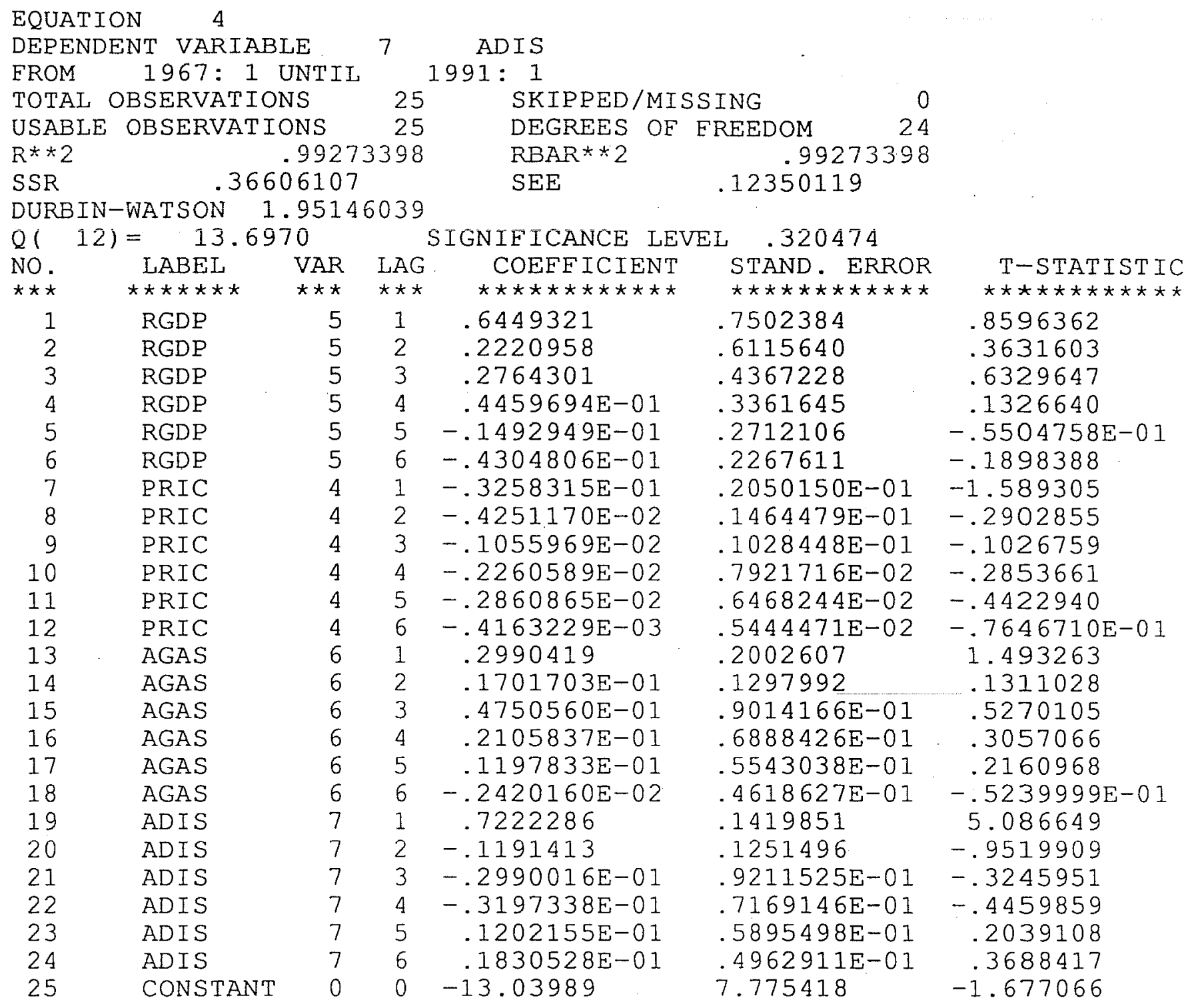


RESPONSES TO ONE-STANDARD DEVIATION SHOCK IN

PRIC

ENTRY

$\begin{array}{rl} & \text { PRIC } \\ 1 & .700061 \\ 2 & .565083 \\ 3 & .336875 \\ 4 & .148411 \\ 5 & -.110045 \mathrm{E}-01 \\ 6 & -.113931 \\ 7 & -.191952 \\ 8 & -.232602 \\ 9 & -.236690 \\ 10 & -.214585 \\ 11 & -.176688 \\ 12 & -.133391\end{array}$

$$
\begin{aligned}
& \text { RGDP } \\
& -.885576 \mathrm{E}-03 \\
& -.197129 \mathrm{E}-02 \\
& -.193975 \mathrm{E}-02 \\
& -.392743 \mathrm{E}-03 \\
& .201672 \mathrm{E}-02 \\
& .404100 \mathrm{E}-02 \\
& .519222 \mathrm{E}-02 \\
& .557216 \mathrm{E}-02 \\
& .540358 \mathrm{E}-02 \\
& .488758 \mathrm{E}-02 \\
& .417360 \mathrm{E}-02 \\
& .339216 \mathrm{E}-02
\end{aligned}
$$

AGAS

$-.223176 \mathrm{E}-01$

$-.267172 \mathrm{E}-01$

$-.237987 \mathrm{E}-01$

$-.156603 \mathrm{E}-01$

$-.844300 \mathrm{E}-02$

$-.500947 \mathrm{E}-02$

$-.385376 \mathrm{E}-02$

-. $314208 \mathrm{E}-02$

$-.244010 E-02$

$-.184383 \mathrm{E}-02$

$-.135948 \mathrm{E}-02$

$-.864248 E-03$

\section{ADIS}

$.118256 \mathrm{E}-01$

$-.215144 \mathrm{E}-01$

$-.481729 \mathrm{E}-01$

$-.572654 \mathrm{E}-01$

$-.518970 \mathrm{E}-01$

$-.364460 \mathrm{E}-01$

$-.162226 \mathrm{E}-01$

$.296238 \mathrm{E}-02$

$.177186 \mathrm{E}-01$

$.267429 \mathrm{E}-01$

$.303677 \mathrm{E}-01$ $.299151 \mathrm{E}-01$

RESPONSES TO ONE-STANDARD DEVIATION SHOCK IN

RGDP L

$\begin{array}{lll}\text { ENTRY } & & \text { PRIC } \\ & 1 & .000000 \\ 2 & -.708262 \mathrm{E}-01 \\ 3 & -.157589 \\ 4 & -.200034 \\ 5 & -.189712 \\ 6 & -.158170 \\ 7 & -.117911 \\ 8 & -.791360 \mathrm{E}-01 \\ 9 & -.453299 \mathrm{E}-01 \\ 10 & -.180392 \mathrm{E}-01 \\ 11 & .139274 \mathrm{E}-02 \\ 12 & .133533 \mathrm{E}-01\end{array}$

\section{RGDP}

$.144542 \mathrm{E}-01$

$.131901 \mathrm{E}-01$

$.122742 \mathrm{E}-01$

$.114653 \mathrm{E}-01$

$.107771 \mathrm{E}-01$

$.101858 \mathrm{E}-01$

$.926101 \mathrm{E}-02$

$.825212 \mathrm{E}-02$

$.733453 \mathrm{E}-02$

$.658201 \mathrm{E}-02$

$.599323 E-02$

$.553383 E-02$

\section{AGAS}

.201711E-01

$.202866 \mathrm{E}-01$

$.187796 \mathrm{E}-01$

$.190350 \mathrm{E}-01$

$.194433 \mathrm{E}-01$

$.191159 \mathrm{E}-01$

$.178087 E-01$

$.167339 \mathrm{E}-01$

$.161438 \mathrm{E}-01$

$.158057 \mathrm{E}-01$

$.154792 E-01$

$.150692 \mathrm{E}-01$
ADIS

$.359256 \mathrm{E}-02$

$.179486 \mathrm{E}-01$

$.329694 \mathrm{E}-01$

$.487619 \mathrm{E}-01$

$.597117 \mathrm{E}-01$

$.641193 \mathrm{E}-01$

$.630959 \mathrm{E}-01$

$.590835 \mathrm{E}-01$

$.536143 E-01$

$.477484 \mathrm{E}-01$

$.421448 \mathrm{E}-01$

$.371808 \mathrm{E}-01$ 
ENTRY

$\begin{array}{rl} & \text { PRIC } \\ 1 & .000000 \\ 2 & .645140 \mathrm{E}-01 \\ 3 & .167617 \\ 4 & .278296 \\ 5 & .362309 \\ 6 & .402616 \\ 7 & .407524 \\ 8 & .380173 \\ 9 & .329895 \\ 10 & .267468 \\ 11 & .202343 \\ 12 & .141910\end{array}$

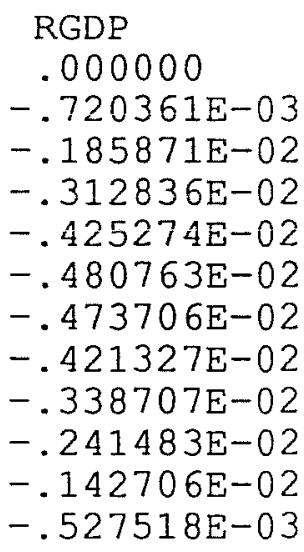

RESPONSES TO ONE-STANDARD DEVIATION SHOCK IN

$\begin{array}{rl} & \text { PRIC } \\ 1 & .000000 \\ 2 & .999226 \mathrm{E}-01 \\ 3 & .168740 \\ 4 & .192812 \\ 5 & .177672 \\ 6 & .134427 \\ 7 & .807062 \mathrm{E}-01 \\ 8 & .268843 \mathrm{E}-01 \\ 9 & -.172695 \mathrm{E}-01 \\ 10 & -.469129 \mathrm{E}-01 \\ 11 & -.619538 \mathrm{E}-01 \\ 12 & -.649614 \mathrm{E}-01\end{array}$

$$
\begin{aligned}
& \text { RGDP } \\
& .000000 \\
& -.183248 \mathrm{E}-02 \\
& -.362359 \mathrm{E}-02 \\
& -.468386 \mathrm{E}-02 \\
& -.459912 \mathrm{E}-02 \\
& -.371918 \mathrm{E}-02 \\
& -.259249 \mathrm{E}-02 \\
& -.159727 \mathrm{E}-02 \\
& -.870782 \mathrm{E}-03 \\
& -.418130 \mathrm{E}-03 \\
& -.189294 \mathrm{E}-03 \\
& -.127065 \mathrm{E}-03
\end{aligned}
$$

AGAS

$.774003 \mathrm{E}-01$

$.731667 \mathrm{E}-01$

$.590798 \mathrm{E}-01$

$.463298 \mathrm{E}-01$

$.372583 E-01$

$.311392 \mathrm{E}-01$

$.260838 \mathrm{E}-01$

$.219965 \mathrm{E}-01$

$.186620 \mathrm{E}-01$

$.158847 \mathrm{E}-01$

$.135117 \mathrm{E}-01$

$.114319 \mathrm{E}-01$
AD I S

$.415391 \mathrm{E}-01$

$.531467 \mathrm{E}-01$

$.540654 \mathrm{E}-01$

$.469685 \mathrm{E}-01$

$.320510 \mathrm{E}-01$

$.146460 \mathrm{E}-01$

$-.139261 \mathrm{E}-02$

$-.138690 \mathrm{E}-01$

$-.214525 \mathrm{E}-01$

$-.241427 \mathrm{E}-01$

$-.228874 \mathrm{E}-01$

$-.189941 \mathrm{E}-01$

\section{ADIS}

$$
\begin{aligned}
& \text { AGAS } \\
& .000000 \\
& -.720824 \mathrm{E}-02 \\
& -.129867 \mathrm{E}-01 \\
& -.155456 \mathrm{E}-01 \\
& -.140538 \mathrm{E}-01 \\
& -.107051 \mathrm{E}-01 \\
& -.797777 \mathrm{E}-02 \\
& -.630724 \mathrm{E}-02 \\
& -.546180 \mathrm{E}-02 \\
& -.508098 \mathrm{E}-02 \\
& -.488742 \mathrm{E}-02 \\
& -.473120 \mathrm{E}-02
\end{aligned}
$$

\section{ADIS}

.112979

$.815965 \mathrm{E}-01$ $.388777 \mathrm{E}-01$ $.230593 \mathrm{E}-02$

$-.256682 \mathrm{E}-01$

$-.385648 \mathrm{E}-01$

$-.384516 \mathrm{E}-01$

$-.324166 \mathrm{E}-01$

$-.240967 \mathrm{E}-01$

$-.159584 \mathrm{E}-01$

$-.939780 \mathrm{E}-02$

$-.474662 \mathrm{E}-02$ 
DECOMPOSITION OF VARIANCE, SERIES

STEP

STAN ERR

2.910256

31.01166

$4 \quad 1.09550$

$5 \quad 1.18282$

$6 \quad 1.27171$

$7 \quad 1.35668$

$8 \quad 1.43045$

$9 \quad 1.48775$

$10 \quad 1.52758$

$11 \quad 1.55226$

12
PRIC

100.0000000

97.6872191

90.1738779

78.7350472

67.5476003

59.2378967

54.0517354

51.2642238

49.9226433

49.3262717

49.0660531

48.9446592

\section{DECOMPOSITION OF VARIANCE, SERIES}

STEP

1

2

3

4

5

6

7

8

9

10

11

12
STAN ERR

$.144813 E-01$

$.197851 \mathrm{E}-01$

$.237161 \mathrm{E}-01$

$.269405 E-01$

$.297530 \mathrm{E}-01$

$.322841 \mathrm{E}-01$

$.344115 \mathrm{E}-01$

$.361054 \mathrm{E}-01$

$.374009 \mathrm{E}-01$

$.383672 \mathrm{E}-01$

$.390826 \mathrm{E}-01$

$.396217 \mathrm{E}-01$
PRIC

.3739682

1. 1930602

1. 4992962

1. 1831424

1.4294736

2.7808630

4.7243249

6.6732214

8.3063163

9.5159793

10.3111670

10.7654896

4

PRIC

RGDP

.0000000

.6054249

2.9166501

5.8214476

7.5661253

8.0923894

7.8658042

7.3814308

6.9166522

6.5745788

6.3672815

6.2646259
AGAS

.0000000

.5023199

3.1518195

9. 1412642

17.2239015

24.9236298

30.9224140

34.8784854

37.1605741

38.3135486

38.8042593

38.9556793
ADIS

.0000000

1. 2050361

3.7576525

6.3022410

7.6623728 .

7.7460841

7.1600463

6.4758600

6.0001303

5.7856010

5.7624061

5.8350357

\section{$5 \quad$ RGDP}

\section{RGDP}

99.6260318

97.8165436

94.8626963

91.6264182

88.2427961

84.9026342

81.9723624

79.6850036

78.1062288

77.1643671

76.7166930

76.5941763
AGAS

.0000000

.1325636

.7064992

1.8959236

3.5974670

5.2730772

6.5362570

7.2990771

7.6223272

7.6393469

7.4955472

7. 3107128
ADIS

.0000000

.8578326

2.9315084

5. 2945158

6.7302633

7.0434256

6.7670557

6.3426979

5. 9651277

5.6803067

5. 4765928

5.3296213 
DECOMPOSITION OF VARIANCE, SERIES

$\begin{array}{rl}\text { STEP } & \text { STAN ERR } \\ 1 & .830407 \mathrm{E}-01 \\ 2 & .115872 \\ 3 & .134181 \\ 4 & .144915 \\ 5 & .151774 \\ 6 & .156557 \\ 7 & .159956 \\ 8 & .162479 \\ 9 & .164451 \\ 10 & .166059 \\ 11 & .167402 \\ 12 & .168536\end{array}$

6 AGAS

PRIC
7.2229505
9.0261365
9.8767644
9.6356571
9.0938657
8.6490765
8.3433887
8.1236774
7.9520425
7.8111415
7.6928893
7.5923578

RGDP

5.9003334

6.0955648

6.5044038

7.3019223

8.2979844

9.2895912

10.1384590

10.8867513

11.5909214

12.2735228

12.9323694

13.5584053

7

ADIS

DECOMPOSITION OF VARIANCE, SERIES

$\begin{array}{rl}\text { STEP } & \text { STAN ERR } \\ 1 & .121006 \\ 2 & .157829 \\ 3 & .180976 \\ 4 & .201545 \\ 5 & .220376 \\ 6 & .236023 \\ 7 & .247854 \\ 8 & .257244 \\ 9 & .265337 \\ 10 & .272463 \\ 11 & .278472 \\ 12 & .283209\end{array}$

PRIC

$$
\begin{array}{r}
.9550686 \\
2.4195714 \\
8.9256466
\end{array}
$$

15.2697813

18.3174851

18.3537418

17.0717781

15.8614782

15.3545721

15.5252411

16.0516700

16.6349542
AGAS

86.8767161

84.4913108

82.3935136

80.8611218

79.7438973

78.9018565

78.2427985

77.6644610

77.1008839

76.5302337

75.9585054

75.4000068
ADIS

.0000000

.3869879

1. 2253183

2. 2012987

2. 8642527

3. 1594757

3. 2753538

3. 3251103

3. 3561523

3. 3851020

3.4162360

3. 4492301

\begin{tabular}{lll}
\multicolumn{1}{l}{ RGDP } & AGAS & \multicolumn{1}{l}{ ADIS } \\
.0881442 & 11.7842191 & 87.1725681 \\
1.3450821 & 18.2660023 & 77.9693443 \\
4.3418314 & 22.8172077 & 63.9153142 \\
9.3542884 & 23.8282377 & 51.5476926 \\
15.1656028 & 22.0453574 & 44.4715548 \\
20.6016607 & 19.6043096 & 41.4402878 \\
25.1623556 & 17.7805656 & 39.9853007 \\
28.6341802 & 16.7968743 & 38.7074673 \\
30.9969350 & 16.4415239 & 37.2069690 \\
32.4677941 & 16.3778453 & 35.6291195 \\
33.3721851 & 16.3541673 & 34.2219776 \\
33.9887107 & 16.2614719 & 33.1148633
\end{tabular}


Appendix 6 .

Model 4: Electricity 
An initial version of this model included State electricity price, real GDP and electricity consumption - the latter two in logarithmic form. The price variable was then dropped because the variance decompositions showed that it did not explain electricity consumption. A tight prior is imposed on the coefficients of electricity in the GDP equation. In fact, real GDP is modelled as a simple autoregression. For this reason, electricity does not contribute to the forecast error of real GDP. The variance decompositions and impulse responses indicate that electricity consumption depends positively on real GDP. 
THE PRIOR IS ...

TIGHTNESS PARAMETER $\quad .20000$

HARMONIC LAG DECAY WITH PARAMETER 1.00000

MEANS AND STANDARD DEVIATIONS AS PERCENTAGE OF OWN LAG

LISTED UNDER THE DEPENDENT VARIABLE

$\begin{array}{lcc} & \text { RGDP } & \text { ELEC } \\ \text { RGDP } & 1.00000000 & .50000000 \\ \text { ELEC } & .01000000 & 1.00000000 \\ \text { MEAN } & 1.00000000 & 1.00000000\end{array}$




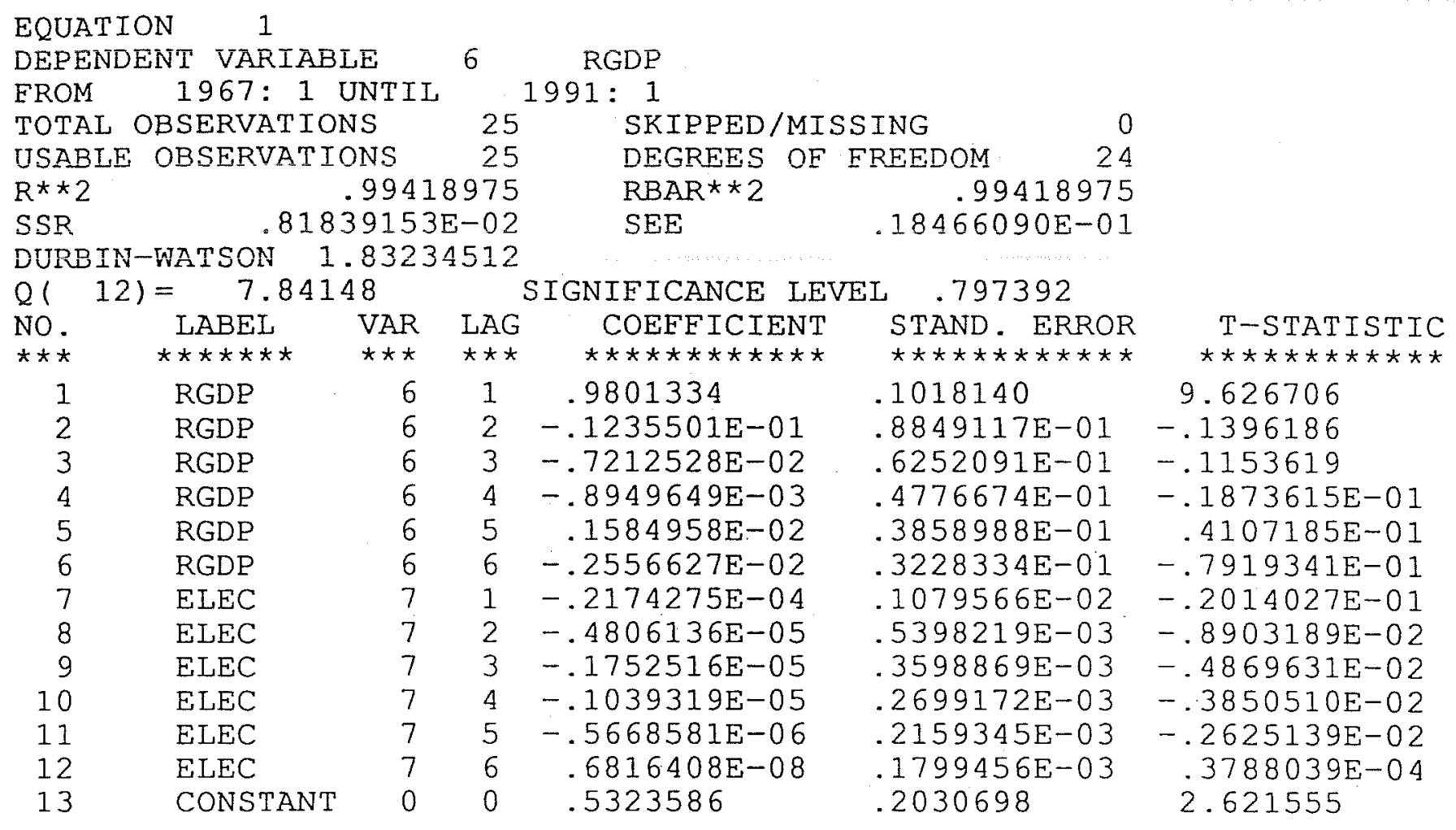




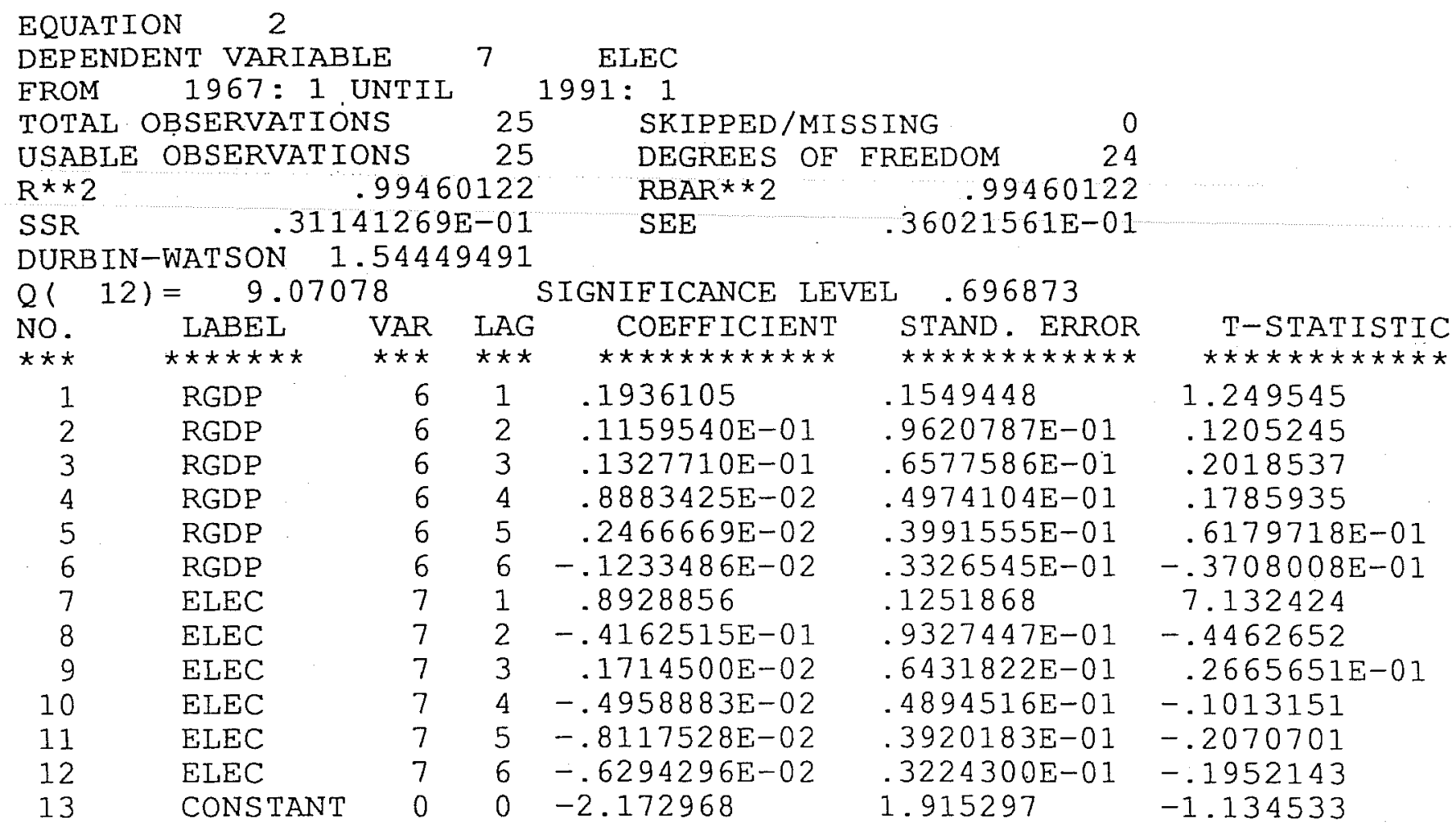




\begin{tabular}{llll} 
ENTRY & \multicolumn{1}{l}{ RGDP } & ELEC \\
& 1 & $.180930 \mathrm{E}-01$ & $.188232 \mathrm{E}-01$ \\
& 2 & $.177331 \mathrm{E}-01$ & $.203100 \mathrm{E}-01$ \\
3 & $.171568 \mathrm{E}-01$ & $.209941 \mathrm{E}-01$ \\
4 & $.164657 \mathrm{E}-01$ & $.216997 \mathrm{E}-01$ \\
5 & $.157819 \mathrm{E}-01$ & $.222260 \mathrm{E}-01$ \\
6 & $.151534 \mathrm{E}-01$ & $.224010 \mathrm{E}-01$ \\
7 & $.145044 \mathrm{E}-01$ & $.222354 \mathrm{E}-01$ \\
8 & $.138817 \mathrm{E}-01$ & $.219136 \mathrm{E}-01$ \\
9 & $.132848 \mathrm{E}-01$ & $.214774 \mathrm{E}-01$ \\
10 & $.127135 \mathrm{E}-01$ & $.209536 \mathrm{E}-01$ \\
11 & $.121667 \mathrm{E}-01$ & $.203673 \mathrm{E}-01$ \\
12 & $.116433 \mathrm{E}-01$ & $.197399 \mathrm{E}-01$
\end{tabular}

RESPONSES TO ONE-STANDARD DEVIATION SHOCK IN ELEC

\begin{tabular}{|c|c|c|}
\hline ENTRY & RGDP & ELEC \\
\hline 1 & .000000 & $.298553 E-01$ \\
\hline 2 & $-.649136 \mathrm{E}-06$ & $.266574 \mathrm{E}-01$ \\
\hline 3 & $-.135933 E-05$ & $.225591 \mathrm{E}-01$ \\
\hline 4 & $-.199525 E-05$ & $.190840 E-01$ \\
\hline 5 & $-.253524 E-05$ & $.159981 E-01$ \\
\hline 6 & $-.297356 E-05$ & $.131537 \mathrm{E}-01$ \\
\hline 7 & $-.330327 E-05$ & $.105947 \mathrm{E}-01$ \\
\hline 8 & $-.353538 E-05$ & $.849347 E-02$ \\
\hline 9 & $-.368624 E-05$ & $.678822 E-02$ \\
\hline 10 & $-.377135 \mathrm{E}-05$ & $.540968 \mathrm{E}-02$ \\
\hline 11 & $-.380415 E-05$ & $.430137 \mathrm{E}-02$ \\
\hline 12 & $-.379602 E-05$ & $.341531 E-02$ \\
\hline
\end{tabular}


DECOMPOSITION OF VARIANCE, SERIES STEP

STAN ERR

.180930E-01

RGDP

$.253342 \mathrm{E}-01$

100.0000000

99.9999999

99.9999998

$.305970 \mathrm{E}-01$

99.9999995

$.381624 \mathrm{E}-01$

99.9999991

99.9999987

99.9999983

99.9999978

435473E-01

$.457063 \mathrm{E}-01$

$.475979 \mathrm{E}-01$

99.9999974

99.9999970

99.9999966

99.9999963

$.507466 \mathrm{E}-01$

$.520652 \mathrm{E}-01$
6

RGDP

ELEC

.0000000

.0000001

.0000002

.0000005

.0000009

.0000013

.0000017

.0000022

.0000026

.0000030

.0000034

.0000037
DECOMPOSITION OF VARIANCE, SERIES

STEP

1

2

3

4

5

6

7

8

9

10

11

12
RGDP

28.4439856

32.3716683

36.3894976

40.4101553

44.3043044

47.9403516

51.2318698

54.1593184

56.7335913

58.9812333

60.9360455

62.6337258
7 ELEC

ELEC

71.5560144

67.6283317

63.6105024

59.5898447

55.6956956

52.0596484

48.7681302

45.8406816

43.2664087

41.0187667

39.0639545

37.3662742 
